This item was submitted to Loughborough's Research Repository by the author.

Items in Figshare are protected by copyright, with all rights reserved, unless otherwise indicated.

\title{
Zoogeomorphological behaviours in fish and the potential impact of benthic feeding on bed material mobility in fluvial landscapes
}

\section{PLEASE CITE THE PUBLISHED VERSION}

https://doi.org/10.1002/esp.4541

\section{PUBLISHER}

(C) John Wiley \& Sons Ltd

\section{VERSION}

AM (Accepted Manuscript)

\section{PUBLISHER STATEMENT}

This is the peer reviewed version of the following article: RICE, S.P. ... et al, 2018. Zoogeomorphological behaviours in fish and the potential impact of benthic feeding on bed material mobility in fluvial landscapes. Earth Surface Processes and Landforms, 44(1), pp. 54-66, which has been published in final form at https://doi.org/10.1002/esp.4541. This article may be used for non-commercial purposes in accordance with Wiley Terms and Conditions for Use of Self-Archived Versions.

\section{LICENCE}

CC BY-NC-ND 4.0

\section{REPOSITORY RECORD}

Rice, Stephen, Andrew Pledger, Julia Toone, and Kate L. Mathers. 2018. "Zoogeomorphological Behaviours in Fish and the Potential Impact of Benthic Feeding on Bed Material Mobility in Fluvial Landscapes".

Loughborough University. https://hdl.handle.net/2134/35721. 
* Corresponding author

1. Loughborough University, Department of Geography, Loughborough, UK,

2. Environment Agency, Trentside, Nottingham, UK, NG2 5FA

3. Eawag, Department of Surface Waters Research and Management, 6047 


\section{ABSTRACT}

18 Foraging by benthivorous fish can affect bed material mobility and sediment flux. This paper collates evidence of benthic feeding effects at local scales and evaluates the possibility that large numbers of foraging fish, each of which accomplishes a small

21 amount of geomorphic work when feeding, may have a cumulative effect across river systems. A first synthesis of research from several disciplines provides a deeper understanding of how fish disturb and condition bed materials with implications for sediment mobility. To evaluate the spatial extent of benthic feeding and therefore the potential for it to have a large-scale effect, the distribution of benthivorous fish is established across a large river network. After quality control, the dataset yields a comprehensive set of fish community information based on over 61,000 individuals and 30 species at 176 sites. The factors that are likely to mediate foraging and its geomorphological effectiveness are considered. A novel scoring system that incorporates three key controls (fish feeding behaviour, fish abundance and fish body size) is then applied across the river network to provide the first prediction of where geomorphologically effective benthic feeding is feasible and its possible relative magnitude. Our results demonstrate that the potential for zoogeomorphic impacts is widespread but variable in space as a function of community composition and the abundance of key benthivores. A preliminary calibration against measured field impacts suggests that benthic feeding may cause measurable geomorphological disturbance at more than $90 \%$ of sites. Together, previous work and this unique analysis suggest that benthic feeding is sufficiently effective and extensive to warrant additional research. Investigating the role of benthivorous fish in fluvial geomorphology is important because it may yield results that challenge the assumption that biota are 
41 irrelevant sources of energy in geomorphological systems. Key research questions 42 and a roadmap to facilitate progress are identified.

43 KEYWORDS: fish, zoogeomorphology, sediment transport, foraging,

44 biogeomorphology

45

46 
Along with microbial life and vegetation (biogeomorphology: Viles, 1988), animals can affect sediment fluxes and moderate landform development, a process regime referred to as zoogeomorphology (Butler, 1995; Hall and Lamont, 2003; Butler and Sawyer, 2012; Holtmeier, 2015). Intricate ecogeomorphological feedbacks can affect the responsible organism or wider community (Naiman et al., 2000; Wheaton et al., 2011;

53 Beschta and Ripple, 2012), in which case the geomorphological effect is a form of ecosystem engineering (Jones et al., 1994; Wright and Jones, 2006; Moore, 2006; Jones, 2012). Zoogeomorphological contributions to ecosystem engineering are therefore part of the evolutionary process that entwines the biotic and abiotic elements of the Earth's surface in the co-development of life and landscape (Meysman et al., 2006, Corenblit et al., 2007; Steiger and Corenblit 2012). In addition, zoogeomorphological processes can present significant socio-economic risks. For example, burrowing of levees on the Secchia River in Italy, possibly by den-building porcupines, contributed to a single structural failure that caused flood damage estimated to be greater than $\$ 500$ million (Orlandini et al., 2015).

Zoogeomorphological investigations in rivers have predominantly focused on iconic species that have impressive visual impacts; for example, on beaver (Castor spp.) where impacts on sediment transfer, hydromorphology and floodplain formation through dam building and meadow construction are plain to see and widely

67 acknowledged (Butler \& Malanson, 1995; Gurnell, 1998; Polvi and Wohl, 2012; Giriat et al. 2016). There has also been some focus on the geomorphological impact of prolific invasive species (Butler, 2006) because they have the potential to disturb landscapes that have not evolved to be resilient to them; for example, non-native crayfish that affect bank stability, sediment recruitment and the mobility of coarse and 
72 fine sediment particles (Statzner et al., 2000, 2003; Harvey et al., 2011; Johnson, 2011;

73 Harvey et al., 2014; Rice et al., 2016; Faller et al., 2016). Other research has

74 considered the impact of less celebrated, somewhat hidden fluvial zoogeomorphic 75 agents ("Cinderella" species, Rice et al., 2012) where the impacts are not apparent to

76 the casual observer but may nevertheless be important; for example, silk-spinning 77 caddis fly larvae that increase bed particle stability (Statzner et al., 1999; Cardinale et 78 al., 2004; Johnson et al. 2009; Albertson et al., 2014).

Almost all this work has demonstrated the impact of river organisms on fluvial 80 processes at small scales, often via relatively limited field observation programmes or in necessarily small ex-situ (and rarely, in-situ) experiments (see reviews in Statzner, 2012; Rice et al. 2012; Albertson and Allen, 2014; Atkinson et al., 2017). There are only a few exceptions, including an estimation of beaver impacts on continental sediment yield (Butler and Malanson, 2005) and studies showing the importance, relative to flooding, of salmonid activity for coarse bedload movement (Hassan et al., 2008) and of signal crayfish (Pacifastacus leniusculus (Dana)) activity for fine sediment entrainment (Rice et al., 2016). In general, the results of small-scale experiments and local observations have not been scaled up. New technologies, including eDNA, are making it easier to establish the distribution of zoogeomorphic agents, and thence their potential to have impacts, over large scales, (Larsen et al., 2017). However, in the absence of evidence demonstrating the impact of river organisms across larger spatial and temporal scales, a pervasive assumption remains that zoogeomorphic effects are inconsequential relative to geophysical forcing for 94 fluvial sediment fluxes and landscape development.

However, biological energy expenditure by large numbers of individual organisms, each of which accomplishes a small amount of geomorphic work, may yield significant 
97 cumulative impacts at larger scales (Philips, 2009; Rice et al., 2016). This idea is not 98 new. Supported by measurements made over several decades, Darwin (1881) 99 quantified the impact of casting by earthworms on downslope soil displacement and 100 estimated that the activity could move as much as $0.057 \mathrm{~kg} \mathrm{~m}^{-1} \mathrm{a}^{-1}$ (5.7 tonnes $\mathrm{km}^{-1}$ in 101100 years) across gentle valley slopes in southern England, smoothing topography 102 and contributing to continental denudation. Different species of earthworm in contrasting environments may have different effects, for example reducing soil erosion in some tropical highlands (Jouquet et al., 2008). In fluvial geomorphology the 105 likelihood of an effect equivalent to that of earthworms has not been demonstrated 106 even though there may be many capable zoogeomorphic agents in river ecosystems 107 (Statzner, 2012; Rice et al., 2012).

108 In this paper we examine a common fish behaviour, foraging in coarse fluvial 109 substrates for food (benthic feeding), and ask whether it could have a large-scale 110 geomorphological impact in rivers, in much the same way that earthworms have an 111 imperceptible but significant impact on terrestrial sediment fluxes and morphology 112 (Darwin, 1881, et seq.). Fish utilise fluvial sediments in several ways. Most fish 113 research has focused on redd construction by salmonids (DeVries, 2012) 114 demonstrating that salmon (Salmo spp.) spawning can affect bed material 115 characteristics (Kondolf et al., 1993; Montgomery et al., 1996), bed permeability and 116 hyporheic exchange (Buxton et al., 2015a), topographic drag (Montgomery et al., 117 1996), bed material stability (Gottesfeld et al., 2004; Buxton et al., 2015b; Hassan et 118 al., 2015), bed load flux (Hassan et al., 2008) and bedform generation (Field-Dodgson, 119 1987, Gottesfeld et al., 2008). A welcome extension to this focus on local effects is 120 found in Fremier et al.'s (2018) attempt to understand the impact of salmonid dispersal 121 and bed destabilisation on long-term fluvial erosion and landscape evolution using a 
122 numerical modelling approach. The physical impacts of nest building by species other

123 than salmonids have also been investigated. Although most of this work has an

124 ecological focus without explicit geomorphological aims, the ecological literature

125 includes the description of nests that are constructed from, or in, river bed sediment

126 by fish including Arctic lamprey (Lethenteron camtschaticum), smallmouth bass

127 (Micropterus dolomi (Lacepède)), three-spined sticklebacks (Gasterosteus aculeatus

128 (L.)), stoneroller (Campostoma anomalum (Rafinesque)) and chub (Nocomis spp.),

129 with N. micropogin (Cope) building spectacular dome-shaped nests that might

130 comprise 10000 individual gravel particles (Lachner, 1952; Winemiller and Taylor,

131 1982; Thorpe, 1988; Sabaj et al., 2000; Rushbrook and Barber, 2008; Shirakawa et

132 al., 2013; Peoples et al. 2016).

133 In comparison to spawning and nesting behaviours, the zoogeomorphic relevance of

134 fish feeding from river bed sediments has not been widely studied (Statzner et al.,

135 2003; Stazner and Sagnes 2008; Fortino, 2006). One strand of ecological research

136 has investigated how foraging of fine organic and mineral sediments on river beds

137 affect benthic resource availability (Power, 1990; Flecker, 1996; 1997; Pringle and

138 Hamazaki, 1998; Gido and Matthews, 2001; Flecker and Taylor, 2004; Cross et al.,

139 2008), but the primary motivation has been to understand the implications for

140 ecological community structure and functioning, not sediment dynamics.

141 Foraging is an interesting behaviour to consider because of this lack of attention by

142 geomorphologists, but also because a small body of work has demonstrated that

143 benthic feeding can be an effective local zoogeomorphic process. If, in addition,

144 foraging is widespread and persistent across river networks, then it is possible that

145 foraging is an important, large-scale influence in fluvial geomorphology. This

146 supposition is investigated in three steps. First, we review research on benthic foraging 
147 and its geomorphological impact, including discussion of those factors that might

148 mediate the presence of foraging behaviours and geomorphological effectiveness at

149 individual sites (e.g. fish community composition, fish body size, fish abundance).

150 Second, based on a classification of UK freshwater fish by feeding behaviour, we

151 examine the distribution of benthic feeding fish across a large river network in the UK.

152 Finally, we use a simple modelling tool that incorporates these factors to provide a

153 first-order prediction of the likelihood that foraging has geomorphological impacts 154 across the same UK river network.

155

156

\section{BENTHIC FORAGING, GEOMORPHIC IMPACTS AND FORAGING CONTROLS}

157 Foraging by fish in coarse-grained river beds

158 Foraging involves the acquisition of food through searching and represents a key determinant of fitness, survival and reproduction in animals (Danchin et al., 2008).

160 Benthic foragers interact with bed sediments in a variety of ways determined by fish 161 size, species, and the environmental setting (Pledger et al., 2014; 2016; 2017). For 162 example, small fish with small mouths may be restricted to feeding within the surface layer, adjusting grain orientations or flipping clasts, whereas large-bodied or highly adapted foragers, may cause whole-grain displacements by digging holes or bulldozing sediments. Fish with large mouths relative to the size of sediment, may also suck in and process particles before depositing them in new positions on the bed.

167 Videos of some of these activities for a selection of UK freshwater fish are included in supplementary material (Supp. 1). Regardless of feeding habitat, foraging fish tend to orientate upstream against the flow (Pledger et al. 2014; 2017), offering hydrodynamic benefits and increased locomotive control. Flow therefore regulates the nature of 
171 foraging behaviour in rivers, meaning the geomorphic impact of lotic vs lentic fishes

172 are likely to be different.

173 Most behavioural studies (e.g. Janssen, 1976, 1978; Sibbing, 1991) consider the food 174 capture, processing and ingestion mechanisms of fish, with little regard for their 175 geomorphic implications. Pledger et al. (2014) therefore developed a classification 176 scheme to describe the manner in which barbel (Barbus barbus (L)) and other cyprinid 177 fishes interact with bed sediments and the specific feeding modes utilised whilst 178 foraging (Figure 1). Behaviours include swim + gulping, gulping, push + gulping and 179 bite + spit (see Pledger et al. (2014) for behaviour descriptions). In a laboratory flume, 180 juvenile barbel foraged water-worked river gravels for chirononomid larvae, a natural 181 prey, using push + gulping, gulping and swim + gulping feeding styles, spending 62 , 18237 and 1\% percent of their time, respectively, utilising each behaviour (Pledger et al., 183 2014; Figure 2a). In the River Idle, underwater video of juvenile chub (Leuciscus 184 cephalus (L)) foraging $0.5 \times 0.5 \mathrm{~m}$ patches of river gravels for natural prey recorded 185 the feeding preferences of an unconstrained wild fish community. Analysis was based 186 on a $30 \%$ subsample of five, 4-hour-long underwater video recordings. Twenty-four 187 discrete feed events were observed; 6 and 18 corresponded to the swim + gulping and 188 gulping feeding styles, respectively (Figure $2 b$ ). The fish were too small to utilise push $189+$ gulping and bite + spit feeding styles. Feed events were short-lived, lasting only 1 190 second on average, and there were four such events per hour, on average.

191 Little is known about the scale of bed disturbance caused by individual feeding events. 192 An ex-situ laboratory flume experiment (Pledger et al. 2014) quantified the spatial extent of foraging by juvenile barbel $(0.0195 \pm 0.009 \mathrm{~m}$ long $)$, when feeding across $1940.138 \mathrm{~m}^{2}$ beds composed of $5.6-1.6 \mathrm{~mm}$ gravels. On average, individual fish 195 searching for bloodworm (chironomidae) fed six times per hour and disturbed $0.05 \mathrm{~m}^{2}$ 
$196(36.9 \%)$ of the bed in each 4-hour observation period. This corresponds to a mean

197 disturbance rate of $0.002 \mathrm{~m}^{2}$ per feed event, equivalent to the hourly disturbance of a

198 circular patch of substrate $50.4 \mathrm{~mm}$ in diameter, which is approximately ten times the

199 maximum experimental particle diameter. In the field, observations of foraged bed

200 surfaces in the River Idle, UK, revealed distinctive scars (Figure 3) created by fish,

201 predominately adult barbel. The size of individual scars varied, but lengths ranged

202 between 87 and $168 \mathrm{~mm}$, and widths between 52 and $140 \mathrm{~mm}$. Further field

203 observations demonstrated that mature fish displaced $64-90 \mathrm{~mm}$ clasts during these

204 events. These data provide some evidence that the spatial extent of individual feeding

205 events is relatively small and scales with fish size. This implies that cumulative

206 foraging extent is at least partly controlled by the size and number of foraging fish in 207 an area, as the latter affects number of feeding events.

209 Foraging and coarse sediment dynamics

210 Foraging has the potential to indirectly affect coarse sediment transport in several 211 ways (Figure 4). First foraging can compromise water-worked structures, dismantling 212 grain-scale fabrics like imbrication, that develop during the waning stages of flood 213 flows and subsequent sub-critical flows, and that stabilise bed materials (Komar and 214 Li, 1986; Clifford et al., 1992; Church et al., 1998; Church, 2010). After foraging, grains 215 are left in less mechanically stable positions with greater degrees of protrusion, more 216 random fabrics and reduced imbrication, all of which have the potential to increase 217 drag, reduce critical entrainment stresses and therefore promote the movement of 218 individual particles under subsequent high flows. 
219 In small (0.2 m-wide) outdoor channels, Stazner et al. (2003) quantified the impact of 220 juvenile barbel on the topography and mobility of randomly arranged, fine gravel beds. 221 Foraging had a significant impact on bed surface topography and the authors 222 observed fish pushing gravel into piles, which they supposed resulted in looser bed 223 sediments with more grains resting in elevated positions, projecting above the 224 surrounding bed. As the number of fish was increased from zero to eight, Statzner et 225 al. (2003) observed a decrease in the critical shear stress for gravel entrainment of $\sim 45 \%$. Pledger et al. (2014) extended this work by considering water-worked gravelly 227 sediments. In a $0.3 \times 10$ m laboratory flume, they quantified the effects of feeding 228 juvenile barbel on particle displacements, bed sediment structures and surface 229 topography. For foraged and unforaged substrates, gravel entrainment and transport 230 fluxes were measured under a moderate transport regime. On average, barbel 231 modified approximately $37 \%$ of the bed area during a four-hour period. Whole-grain 232 displacements and adjustments of grain orientations resulted in increased 233 microtopographic roughness, reduced structure and so, increased sediment mobility. 234 Specifically, grain disturbance increased bedload flux and the number of entrained 235 grains by $60 \%$ and $82 \%$, respectively, when comparing transport data from foraged 236 and unforaged beds.

237 Laboratory experiments were extended to a field situation (River Idle, UK) where the 238 effects of foraging fish, primarily rheophilic cyprinids, on gravel structures, surface 239 topography, grain-size distributions and bedload transport, were assessed (Pledger et 240 al., 2017). Large $(0.5 \times 0.5 \times 0.1 \mathrm{~m})$ trays of gravel, water-worked under ambient flows 241 and seeded with food (hempseed, cannabis sativa), were either exposed to foraging 242 fish or not by deploying exclusionary cages. Sections of experimental trays were 243 retrieved from the field and exposed to an entrainment flow in a laboratory flume to 
quantify changes in sediment mobility after foraging. Benthic feeding fish disturbed, on average, $74 \%$ of the substrate during a twelve-hour period, displacing particle sizes up to and including $90 \mathrm{~mm}$ clasts, increasing bed surface microtopography and grain

247 protrusion, coarsening substrates and loosening surface structures (Pledger et al., 248 2017). These changes caused significant reductions in sediment mobility from the 249 experimental trays, with declines in sediment flux and total transported mass detected 250 from foraged substrates. This result contrasts with ex-situ experiments (cf. Pledger et 251 al. 2014, 2016) where foraging increased sediment transport and reflects 252 displacement of finer grains by fish to leave a coarser lag within the experimental trays. 253 It is likely that entrainment from the surrounding bed, where fine grains were deposited 254 by fish and left in relatively unstable positions, would be enhanced.

255 In addition to changing clast arrangements and undoing stabilising structures, foraging 256 can affect local grain size characteristics with potential consequences for sediment 257 transport. During the in-situ experiment, Pledger et al. (2017) detected significant 258 changes in the size distribution of experimental tray substrates with foraging resulting in better sorted and coarser sediments, as indicated by increases in all grain-size 260 percentiles. Benthic foragers preferentially displaced finer particle sizes from 261 experimental trays which caused a statistically significant, $2.8 \mathrm{~kg}(33 \%)$ decrease in 262 the total mass of sediment remaining in foraged trays. Observations of grain 263 displacements showed that large clasts were consistently pushed upstream, typically 264 by barbel utilising the push + gulping behaviour. However, fine sediments tended to 265 be deposited downstream of their original locations because fish feeding using the 266 gulp + spit behaviour, collected and processed sediments then drifted downstream to 267 conserve energy, before ejecting particles from their mouths onto the bed surface. 268 These behaviours, which sort sediment locally, are important because they may 
269 increase sediment patchiness, which is known to affect sediment mobility and

270 transport (Wiberg and Smith, 1987; Kirchner et al., 1990; Buffington and Montgomery,

271 1997; Ferguson, 2003). Furthermore, finer grains deposited on the sediment surface

272 downstream of their origin, in relatively exposed positions without the structural

273 stability of water-worked counterparts, are likely to be relatively more susceptible to 274 entrainment.

275 A third way in which foraging may affect bedload mobility is via near bed hydraulics.

276 This has not been assessed, but in the same way that Montgomery et al. (1996) 277 suggest that redd construction might affect topographic drag, foraging probably affects 278 grain drag. In particular, increases in surface protrusion, rugosity and the 279 microtopography associated with grain rearrangement and feeding scars may 280 increase grain roughness resulting in increased drag and lower near-bed velocities 281 and shear. Such an affect would reduce grain mobility by lowering bed shear stress.

282 Figure 4 also highlights the potential for impacts on bed material transport to feed back 283 to the environmental, predator and prey factors that determine foraging intensity and 284 extent. For example, transport might affect bed material grain size distribution and so 285 the ease with which prey can be found and habitat suitability for prey.

286 Field observations of foraging at reach scales

287 At 12 sites (covering approximately $600 \mathrm{~m}^{2}$ ) along a reach of the River Idle, Pledger 288 et al. (2017) quantified the local rate of foraging impact on riffles and considered the 289 nature and spatial distribution of the foraging disturbance. This was achieved by 290 installing disturbance indicators (spray-painted steel washers; 38 × $2 \mathrm{~mm}$ ) across 291 feeding riffles, at an approximate density of one per square meter, and assessing their 292 displacement over a 24-hour period in the absence of any hydraulic changes. Each 
293 riffle recorded some disturbance, implying the impact of foraging was widespread, but 294 the number of washers disturbed varied between riffles, ranging between 3.3 and $29556.7 \%$ (representing between 0.8 and $39.7 \mathrm{~m}^{2}$ of bed area). During each 24-hour 296 period, an average of $26.1 \%$ of washers were disturbed, equivalent to $13.6 \mathrm{~m}^{2}$ per riffle.

297 Disturbance was not patchy, but evenly distributed across riffles, reflecting the way in 298 which fish foraged systematically, combing entire riffles for prey. These findings 299 highlight the potential importance of benthic foraging as a widespread and temporally 300 persistent geomorphic activity in some rivers.

301

302

Controls of foraging intensity

303 Published studies of the controls of foraging have focused on species, species 304 interactions, temperature and fish size. The joint impacts of barbel, gudgeon (Gobio 305 gobio (L)) and the spinycheek crayfish (Faxonius limosus (Rafinesque)), in two306 species parings, on the condition and mobility of fine-grained sediments were 307 investigated by Stazner and Sagnes (2008). Exposure to each species resulted in 308 greater sediment mobility, but their net effects when paired were generally less than 309 the sum of the individual impacts. This suggests that interactions between the species 310 in a local community are an important control on foraging behaviour. Canal et al. (2015) 311 demonstrated that disturbance rates amongst species including stone loach 312 (Barbatula barbatula (L)) and the South-west European nase (Parachondrostoma 313 toxostoma (Vallot)) are partly controlled by ambient water temperature. Surface 314 sediment disturbance by these species increased by $200-300 \%$ for an increase in 315 water temperature from 10 to $20^{\circ} \mathrm{C}$. Fish are ectothermic and are unable to regulate 316 corporal temperature with metabolic heat, so they rely on ambient water temperature 317 to drive metabolism. The result of lower water temperatures is therefore reduced 
318 activity, including reduced feeding (Lemons and Crawshaw, 1985). It is likely that as 319 energy requirements and foraging activity vary through the year as a function of 320 temperature, so zoogeomorphic activity may vary seasonally.

321 In ex-situ flume experiments, Pledger et al. (2016) examined the role of fish size and 322 species as controls of sediment disturbance using four size classes of barbel (4-5", 5323 6", 6-8", 8-10" in length) and one of chub (8-10"). The area of disturbed substrate, 324 foraging depth, microtopographic roughness, bedload flux and total transported 325 bedload all increased with fish size, whereas sediment structure (measured by 326 imbrication) decreased. With regard to species effects, 8-10" barbel foraged a larger 327 area of the riverbed than chub and had a greater impact on microtopographic 328 roughness and sediment structure. Structural and topographic changes by both 329 species were associated with increased sediment mobility, but the bed load flux and 330 total transported mass after foraging by barbel was $150 \%$ and $98 \%$ greater, 331 respectively, than that after foraging by chub.

332 In addition to these factors, foraging extent and intensity, and therefore the cumulative 333 zoogeomorphic impact of foraging, is likely to be influenced by a broader set of biotic and abiotic factors that moderate the relationship between energy gains and costs during foraging. These factors are neither fully defined nor understood. Flow and bed material characteristics are likely to be important as these affect the energy 337 expenditure required to move between sites and manipulate clasts to expose and 338 consume prey. Meteorological factors including barometric air pressure and air 339 temperature have been shown to influence catch rates (which are indicative of feeding 340 rates) in recreational fisheries (Margenau et al., 2003; Stoner et al., 2004). The ratio 341 of prey availability to predator abundance is also likely to be important as this affects 342 the intensity with which individuals must forage to successfully gain sustenance in 
competition with other individuals. Characteristics of the fish community, including some species traits are also likely to be important. For example, research has found that shoal-feeding fish are less timid, will spend less time exhibiting vigilant behaviour and will forage for longer when feeding (Pitcher \& Parrish, 1993). Shoaling behaviour may therefore increase the zoogeomorphic impact of gregarious fish species such as

348 B. barbus. Finally, there may be anthropogenic controls on foraging, including the role of anglers in encouraging benthic foraging by deploying ground baits. Pledger (2015) completed a field experiment that examined how bait density and type (hemp seed, fishmeal pellets) affected foraging behaviour. Feeding styles were different when fish foraged for natural prey versus bait, suggesting that heavily fished river reaches may experience different degrees of bed disturbance.

THE EXTENT AND POTENTIAL ZOOGEOMORPHIC IMPACT OF BENTHIC FORAGING AT CATCHMENT SCALES

357 Given the small-scale impact of individual fish, any large-scale cumulative impacts must be dependent on the distribution of benthivorous fish across river networks and the moderation of individual geomorphic efficacy by biotic and abiotic controls on 360 foraging intensity. It is therefore reasonable to suppose that the potential for a largescale zoogeomorphic impact increases with the spatial distribution of benthivorous fish and, based on the evidence presented above, with intensity factors including the abundance and size of those fish.

364 To evaluate the potential for large-scale geomorphological effects we use fisheries data from a large UK river network as a case study, to investigate the distribution of benthic feeding fish in space and determine how widespread they are. In turn, we use 
a simple modelling tool that incorporates measures of feeding behaviour, fish size and abundance, which are the three key biotic controls of ecosystem engineering potential (Moore, 2006), to provide a first-order prediction of the likelihood that benthic feeding has geomorphological impacts across that UK river network.

Study Area and Methods

373 The River Trent $\left(10,452 \mathrm{~km}^{2}\right)$ rises in the Pennines and the low hills of the western 374 Midland Plain around Birmingham and flows east and north through the English 375 Midlands and ultimately into the Humber estuary (Figure 5a). Millstone Grit and 376 Carboniferous Limestone sequences in the Pennines give way to Triassic Mercian 377 Mudstones and sandstones through the majority of the catchment, with local 378 anomalies including the Charnwood Precambrian volcanics in Leicestershire and 379 Jurassic limestones in Lincolnshire. Annual rainfall varies between approximately $3802000 \mathrm{~mm}$ in the northern uplands, at elevations around $630 \mathrm{~m}$ a.s.l., to $550 \mathrm{~mm}$ in the 381 distal eastern areas. At North Muskham, where the catchment area is $8,231 \mathrm{~km}^{2}(79 \%)$ 382 mean daily discharge is $89.5 \mathrm{~m}^{3} \mathrm{~s}^{-1}$, the mean annual flood (2-year return period) is $383434.3 \mathrm{~m}^{3} \mathrm{~s}^{-1}$ and the largest flood on record (since 1961) is $1000.2 \mathrm{~m}^{3} \mathrm{~s}^{-1}$. Land-use is 384 predominantly agricultural (42\% grassland, $30 \%$ arable) with $18 \%$ urban cover, $7 \%$ 385 woodland and 3\% mountain heath and bog. The Trent provides a useful case study 386 because of its scale and environmental diversity, which encompasses a range of river 387 types including rain- and groundwater-fed gravel-bed rivers in the dramatic valleys of 388 the Peak District (e.g. R. Dove), lower gradient gravel-bed rivers draining north across 389 the Midland Plain (e.g. R. Mease) and the Trent itself, which flows in a broad low390 gradient valley through finer alluvium as it approaches the Humber. 
391 Between 2013 and 2015, the Environment Agency of England surveyed fish 392 populations at 238 sites across the Trent catchment and we used this data in our 393 analysis. At some sites, samples were collected in multiple years and in these cases 394 the most recent data were selected. Samples were collected using several different 395 methods. To ensure data consistency and quality, we retained only electrofishing 396 samples collected in wadable watercourses where stop nets were deployed at both 397 ends of the sampled reach ( $n=176)$. Some samples were collected by electrofishing 398 the survey reach once $(n=111)$, and others included $2(n=49)$ or $3(n=16)$ passes. The 399 different number of passes might have introduced differences in the quality of 400 individual samples, because more passes may have caught more fish or sampled 401 more species. However, there is no relation between fish catch or species richness 402 and the number of electrofishing passes in the dataset and we therefore assume that, 403 for our purposes, all samples are of equivalent quality. The final dataset provided 404 reasonable spatial coverage of the river network, but excluded deeper channels 405 including most of the mainstem Trent where standard fish sampling methods cannot 406 routinely be deployed (Figure 5b).

407 The final dataset contained a total of 61,055 individual fish comprising 30 species 408 (Table 1), caught in reaches that were on average $110.6 \mathrm{~m}$ long $(\mathrm{SD}=25.0 \mathrm{~m})$ and $4095.9 \mathrm{~m}$ wide $(\mathrm{SD}=3.4 \mathrm{~m})$. Maitland (2004) lists 57 established fish species for Britain's 410 fresh waters, including introduced species and marine fish that are occasionally found 411 inland. The 30 taxa recorded in the Trent samples therefore represent $53 \%$ of possible 412 UK species.

413 To assess the potential for geomorphic work at any given survey site, a benthic impact 414 score (BIS) was calculated for each species that was present as: 
416 where FBS is a feeding behaviour score for the species, mass score (MS) is a score 417 for the average adult mass of the species, $n$ is fish abundance at the site and $A$ is survey area. BIS weights each of the component parts equally, in the absence of any evidence to suggest a more appropriate alternative weighting. Feeding behaviour scores differentiate between the dominant feeding mechanism of each fish species at

421 the adult stage. It is recognised that feeding behaviour in fishes is complex and 422 dependent on a range of variables, but for the purposes of assessing potential 423 geomorphic impact a simple nominal classification establishes if species do or do not 424 affect the bed when feeding. Taxa were assigned benthic feeding scores FBS, based 425 on their dominant feeding mechanisms (Table 1): piscivorous and parasitic = 0 ; 426 opportunistic $=1$; benthic $=2$. Opportunistic species feed from the bed some of the 427 time (e.g. chub) and benthic species are obligate benthic feeders, evolved and 428 physiologically adapted to benthic foraging (e.g. barbel). Atlantic Salmon were 429 assigned a score of 0 because negligible feeding is expected amongst returning adults.

430 Fish size has been shown to influence geomorphic impact (e.g. Pledger et al., 2016), 431 and we incorporated that in BIS by assuming that the force a fish is able to exert on 432 the bed when foraging is proportional to its mass. Length ranges for each adult species 433 were taken from Maitland (2004) and an average length calculated. An average mass 434 for each species was subsequently calculated using the Environment Agency's in435 house length-mass calculator (National Fish Population Database), which is routinely 436 used to convert length observations for a species into mass because direct mass 437 measurements in the field are time-consuming. Mass scores were then assigned 438 based on natural breaks in the distribution when average adult masses for all taxa 439 were sorted by magnitude: $0-13 g=0 ; 14-99 g=1 ; 100-499 g=2 ; 500-1499 g=$ 
4403 and; $1500-4000 \mathrm{~g}=4$ (Table 1 ). The decision to score fish lighter than $14 \mathrm{~g}$ at zero

441 may be conservative, because small fish can disturb sands and detritus, but it reflects

442 what we know about impact on bed material mobility based on the smallest barbel 443 used by Pledger et al., (2014). In those experiments, the smallest group of barbel used 444 had an average mass of $14 \mathrm{~g}$ and rearranged gravels between 5.6 and $16 \mathrm{~mm}$ in 445 diameter, with an impact on subsequent bedload transport.

446 Finally, BIS includes a measure of abundance because we assume that the number 447 of feeding events increases with the number of individuals that are present (Statzner 448 et al., 2003). Abundance was normalised by sample area to account for differences in 449 the length and width of the reaches that were electrofished at different sampling sites. 450 BIS therefore includes the three key drivers identified by Moore (2006) as 451 determinants of impactful ecosystem engineers in streams: behaviour, body size and 452 density. At each site, the BIS scores for each species present were calculated, then 453 added together to yield a single index of potential geomorphological impact for that 454 site, $\sum$ BIS site. For each species, across all sites, the sum of BIS scores, $\sum$ BIS $_{\text {species, }}$ 455 indicates the sum magnitude of that species potential geomorphic impact via foraging. 456

\section{Distribution and abundance of benthivorous fish}

458 Of 30 species recorded, 13 are benthic specialists and 12 are opportunistic benthic feeders (Table 1). The total number of individuals in these two groups accounted for $52.6 \%$ (32,118 fish) and $46.2 \%$ (28,185 fish) of the total catch, respectively. Benthic

461 feeding fish therefore are abundant and dominated the overall sample (98.8\%). This 462 abundance is matched by broad spatial distribution, such that benthic feeding fish are 463 ubiquitous in the Trent catchment (Figure 6). Of the 25 benthic and opportunistic 
species, six have small average adult body masses below $14 \mathrm{~g}$. This group of small

465 fish were abundant, comprising 29,704 individuals; notably with 20,557 minnows. Therefore, almost half of all benthivorous fish (49.3\%) were assigned MS $=0$ and so are not predicted to have any impact on sediment disturbance. In the absence of the necessary research to establish whether fish this small affect bed sediments, this is appropriate.

There were 19 species of benthivorous fish with an average adult mass more than 14

g, and therefore predicted to have an individual effect on bed materials (FBS $x$ MS > and the number of sites where these 19 species were found increased approximately as the square root of their abundance (Figure 7). Notably, the most abundant and widespread species tended to have lower MS and FBS, and are therefore less likely to be effective individual geomorphic agents (Figure 7). For example, 21,800 bullhead

477 (Cottus gobio) were found at 147 sites (Figure 8a). Although these are aggressive 478 benthic feeders they are small fish (10-15cm long, $28 \mathrm{~g}$ average adult weight) and so unlikely to disturb large particles, scoring FBS x MS = 2. In contrast, 23 barbel and 80 common bream (Abramis brama), which are large fish (average adult weights of 1451 $\mathrm{g}$ and $1231 \mathrm{~g}$ ) that are known to disturb gravelly and silty substrates (FBS $\times$ MS =6), were found at 14 sites (Figure $8 b$ ).

Across the catchment, 174 of the 176 sites had $\Sigma B I S_{\text {site }}>0$, suggesting that the 486 potential for geomorphic foraging impact is widespread (Figure 9). The distribution of 487 scores was strongly positively skewed: $86 \%$ of sites had scores between 0 and 1 and 
the mean score was 0.76 , but the maximum score for a single site was 13.47 . There are two sites in the database on the River Idle that fall within the study area used by Pledger et al. (2017). These two sites have $\Sigma$ BIS $S_{\text {site }}=0.138$ and 0.253 , respectively, 491 equivalent to the $3^{\text {rd }}$ and $10^{\text {th }}$ percentiles of all site scores; that is, between 90 and $97 \%$ 492 of sites have higher $\Sigma B I S_{\text {site }}$ scores. Given that the fish communities at the Idle sites 493 were effective in disturbing bed materials sufficiently to affect bed mobility (Pledger et 494 al., 2017), this comparison provides a limited qualitative calibration of the scoring 495 system. It suggests, albeit very crudely, that the $\Sigma$ BIS site scores recorded at $90 \%$ of 496 sites could be associated with measurable geomorphic work.

497 High $\Sigma \mathrm{BIS}_{\text {site }}$ scores tend to be in the northern and western parts of the catchment, 498 specifically the upper Trent, River Sow, those tributaries (the Dove particularly) that 499 drain the upland areas of the Peak District and the River Mease (Figure 9). The greater 500 potential for zoogeomorphic work in these rivers reflects differences in the community 501 composition. There is an unsurprising association between $\Sigma \mathrm{BIS}$ site and bullhead 502 abundance, with large numbers of bullhead on the Sow, Mease and upper Trent 503 (Figure 8a) responsible for higher scores on those rivers. High scores in the Dove and 504 Derwent catchments are again associated with bullhead, but also with brown trout. 505 Values of $\sum$ BIS species show that bullhead and brown trout contribute most to the 506 aggregate potential of all species to do geomorphic work (Figure 10), being 507 responsible for $75.3 \%$ and $8.8 \%$, respectively, of the total score across all species. 
510 The purpose of this paper is to evaluate whether foraging by fish is a viable influence

511 of bedload sediment flux across fluvial landscapes. The research reviewed above

512 confirms that foraging fish can disturb coarse bed sediments, with implications for local

513 sediment sorting, bed material fabric and structure, and bed load transport, but the

514 body of evidence is small and there are many knowledge gaps. A key gateway

515 question, affecting the perceived value of investigating these gaps, is whether benthic

516 feeding is sufficiently common and widespread to have a potential cumulative impact

517 on bed material condition and bedload fluxes at catchment scales.

518 Our analysis of benthivorous fish in the River Trent network provides a first ever 519 attempt to address this question by establishing a scoring system that uses fish data 520 to identify sites where the river bed is prone to be disturbed and conditioned by benthic 521 feeding fish. It is important to emphasize that BIS scores indicate the potential for 522 benthic foraging to accomplish geomorphic work; they are not a measure of that effect.

523 BIS is based on Moore's (2006) criteria for effective ecosystem engineering in rivers 524 - organism abundance, size and behaviour. Although these three criteria are proven 525 to be relevant at local scales by the work of Pledger et al. $(2016,2017)$ and others, 526 the nature of the relations between these factors and geomorphic work is largely 527 unknown. In addition, other biotic and abiotic factors that are likely to affect the 528 geomorphic work done by benthivorous fish (Figure 4) are not included; for example, 529 bed-material grain size distribution. Furthermore, although we have made some 530 attempt to calibrate the scores against known zoogeomorphic impacts on the River 531 Idle, we cannot easily translate the scores into meaningful geomorphological 532 expression. Although the scoring system is relatively unsophisticated and untested, it 533 is an appropriate, low-cost, high-level index for a first attempt to establish the extent 534 of site and species potentials. 
535 In this context, calculated BIS scores indicate that the potential for zoogeomorphic 536 impacts is widespread (benthic feeding fish are widespread and abundant) and

537 variable in space as a function of community composition and the abundance of key 538 benthivorous species. We do not make any greater claims, but suggest that this 539 analysis, alongside previous research reviewed above, provide sufficient evidence to 540 warrant additional investigation of the role of benthivorous fish in fluvial 541 geomorphology. The case for redd-building impacts has been established over a long 542 period but is now yielding large-scale assessments of the impacts that salmonids 543 might have on millennial timescales and orogenic spatial scales (Fremier et al., 2018).

544 The aim of investigating foraging impacts is similar; to establish the detailed 545 understanding of processes necessary to develop local and basin scale transport 546 models that incorporate foraging effects. There are three key elements of the problem 547 that together define a roadmap for future research in this area.

548 (1) Quantify the impact of benthic feeding by common freshwater fishes, individually 549 and in typical community structures, including an understanding of the role of key biotic 550 and abiotic controls (Figure 4). This could be addressed using controlled flume 551 experiments to establish which common, benthivorous, fish species are capable of 552 conditioning river bed sediments (altering size characteristics and structural 553 organisation). The same experiments could investigate the impact of this conditioning 554 on transport mechanics and sediment fluxes, and establish general relations in which 555 the mechanistic impact is parameterised using generalisable parameters. Key abiotic 556 factors (e.g. flow rate, bed material characteristics) and biotic factors (fish size, prey 557 characteristics, inter-species competition) should be manipulated to understand and 558 quantify their effect on bed conditioning and particle mobility. 
559 (2) Develop predictive models of this disturbance effect based on fish community 560 characteristics and the spatiotemporal distribution of relevant foraging behaviours in 561 rivers. Establish typical rates of benthic bed disturbance and the extent to which 562 ecological factors (e.g. community composition, demography, abundance, life stage) 563 and environmental factors (e.g. substrate type, flow regime) control the magnitude and 564 spatiotemporal distribution of bed-conditioning activity. Simple devices like washer 565 disturbance indicators would be valuable for gathering such information. In addition, 566 field experiments (sensu Pledger et al., 2017) could investigate the extent of substrate 567 conditioning by wild fish communities.

568 (3) Estimate the cumulative impact of benthic feeding for river-scale sediment fluxes. 569 With a fuller understanding of which species and fish communities disrupt bed 570 materials and how abiotic and biotic factors mediate their effects, a feasible goal 571 becomes the development of a generic model for predicting the impact of foraging on 572 sediment flux. This could, for example, be built using a spatially-explicit numerical 573 sediment routing model, applied with Shields' values that have been adjusted to reflect 574 the change in bed stability caused by foraging disturbance.

575 Why is this important? Because, despite seminal work (Darwin, 1881), growing 576 theoretical understanding (Steiger and Corenblit 2012), strong empirical evidence 577 (Philips, 2009; Rice et al., 2016), technological innovations (Larsen et al., 2017) and 578 societal implications (Orlandini et al., 2015), geomorphologists have not fully assessed 579 or incorporated the role of biological energy in models of geomorphological processes. 580 The relative exclusion of biological processes from geomorphological thinking may 581 have happened for a complex mixture of reasons, including historic accident, lack of 582 conceptual frameworks and the inertia of conventional thought (Johnson, 2002). 583 Nevertheless, it is possible that the failure to assess the potential geomorphic impact 
584 of common river fauna is a constraint on our understanding of fluvial sediment 585 dynamics and landscape change (National Research Council, 2010; Atkinson et al., $5862017)$ and is therefore an omission worthy of greater attention.

587

588 


\section{ACKNOWLEDGEMENT}

590 We are very grateful to Matthew Johnson for drawing Figure 1 and to James Smith for

591 useful discussions pertaining to the research. The videos in supplementary material 592 were collected by co-author Pledger, except for the log perch sequence, which was 593 shot by Noel Burkhead (formerly USGS) who has kindly given his permission for us to 594 use this. The Environment Agency of England supplied the fish survey information 595 under licence, but this does not mean that the analysis or arguments presented here 596 have any official status or that the Environment Agency endorse the authors or our 597 use of the information supplied. Contains Environment Agency information (C) 598 Environment Agency and database right. We are grateful for two anonymous reviews 599 that improved the manuscript.

600 
602 Albertson LK, Sklar LS, Pontau P, Dow M, BJ Cardinale. 2014. A mechanistic model 603 linking insect (Hydropsychidae), silk nets to incipient sediment motion in gravel-

604 bedded streams. Journal of Geophysical Research: Earth Surface 119: 1833-1852.

605 https://doi.org/:10.1002/2013JF003024

606 Atkinson CL, Allen DC, Davis L, Nickerson ZL. 2017. Incorporating ecogeomorphic

607 feedbacks to better understand resiliency in streams: A review and directions

608 forward. Geomorphology 305: 123-140.

609 https://doi.org/10.1016/j.geomorph.2017.07.016

610 Beschta RJ, Ripple WJ. 2012. The role of large predators in maintaining riparian

611 plant communities and river morphology. Geomorphology 157: 88-98.

612 https://doi.org/10.1016/j.geomorph.2011.04.042

613 Buffington JM, Montgomery DR. 1997. A systematic analysis of eight decades of 614 incipient motion studies, with special reference to gravel-bedded rivers. Water

615 Resources Research 33: 1993-2029. https://doi.org/10.1029/96WR03190

616 Butler DR, Malanson GP. 1995. Sedimentation rates and patterns in beaver ponds in 617 a mountain environment. Geomorphology 13: 255-269. https://doi.org/10.1016/0169618 555X(95)00031-Y

619 Butler DR, Malanson GP. 2005. The geomorphic influences of beaver dams and 620 failures of beaver dams. Geomorphology 71: 48-60.

621 https://doi.org/10.1016/i.geomorph.2004.08.016.

622 Butler DR, Sawyer CF. 2012. Introduction to the special issue - zoogeomorphology 623 and ecosystem engineering. Geomorphology 157-158: 1-5.

624 https://doi.org/10.1016/i.geomorph.2012.02.027

625 Butler DR. 1995. Zoogeomorphology Animals as geomorphic agents. Cambridge 626 University Press, UK

627 Butler DR. 2006. Human-induced changes in animal populations and distributions, 628 and the subsequent effects on fluvial systems. Geomorphology 79: 448-459.

629 https://doi.org/10.1016/i.geomorph.2006.06.026

630 Buxton TH, Buffington JM, Tonina D, Fremier AK, Yager EM. 2015a. Modeling the 631 influence of salmon spawning on hyporheic exchange of marine-derived nutrients in 632 gravel stream beds. Canadian Journal of Fisheries and Aquatic Sciences 72: 1146633 1158, https://doi.org/10.1139/cjfas-2014-0413

634 Buxton TH, Buffington JM, Yager EM, Hassan MA, Fremier AK. 2015b. The relative 635 stability of salmon redds and unspawned streambeds, Water Resources Research 636 51: 6074-6092. https://doi.org/10.1002/2015WR016908 
637 Canal J, Laffaille P, Gilbert F, Lauzeral C, Buisson L. 2015. Influence of temperature 638 on surface sediment disturbance by freshwater fish: a microcosm experiment,

639 Annales de Limnologie 51: 179-188. https://doi.org/10.1051/limn/2015012

640 Cardinale BJ, Gelmann ER, Palmer MA. 2004. Net spinning caddisflies as stream 641 ecosystem engineers: the influence of hydropsyche on benthic substrate stability.

642 Functional Ecology 18: 381-387.

643 Church M, Hassan MA, Wolcott JF.1998. Stabilizing self-organized structures in 644 gravel-bed stream channels: Field and experimental observations. Water Resources 645 Research 34: 3169-3179. https://doi.org/10.1029/98WR00484

646 Church M. 2010. Gravel-bed rivers. In Burt TP and Allison RJ (Eds) Sediment 647 Cascades: An Integrated Approach, John Wiley and Sons, Chichester, 241-269 648 https://doi.org/10.1002/9780470682876.ch9

649 Clifford NJ, Richards K. Robert A. 1992. The influence of microform bed roughness 650 elements on flow and sediment transport in gravel bed rivers: comment on a paper 651 by Marwan A Hassan and Ian Reid. Earth Surface Processes and Landforms 17: 652 529-534. https://doi.org/10.1002/esp.3290170511

653 Corenblit D, Steiger J, Gurnell A, Tabacchi E. 2007. Darwinian origin of landforms.

654 Earth Surface Processes and Landforms 32: 2070-2073.

655 https://doi.org/10.1002/esp.1536

656 Cross WF, Ramirez A, Santana A, Santiago LS. 2008. Toward Quantifying the 657 Relative Importance of Invertebrate Consumption and Bioturbation in Puerto Rican 658 Streams. Biotropica 40: 477-484. https://doi.org/10.1111/j.1744-7429.2007.00388.x

659 Danchin E, Giraldeau L Cezilly F. (2008). Behavioural Ecology. New York: Oxford 660 University Press.

661 Darwin CR. 1881. The Formation of Vegetable Mould, through the action of worms, 662 with observations on their habitat. John Murray, London.

663 DeVries P. 2012. Salmonid influences on rivers: A geomorphic fish tail.

664 Geomorphology 157-158: 66-74. https://doi.org/10.1016/j.geomorph.2011.04.040

665 Faller M, Harvey GL, Henshaw AJ, Bertoldi W, Bruno MC, England J. 2016. River 666 bank burrowing by invasive crayfish: Spatial distribution, biophysical controls and 667 biogeomorphic significance. Science of The Total Environment 569-570: 1190-1200. 668 https://doi.org/10.1016/j.scitotenv.2016.06.194

669 Ferguson RI. 2003. The missing dimension: Effects of lateral variation on 1-D 670 calculations of fluvial bedload transport. Geomorphology 56: 1-14.

671 https://doi.org/10.1016/S0169 - 555X 
672 Fremier AK, Yanites BJ, Yager EM. 2018. Sex that moves mountains: The influence

673 of spawning fish on river profiles over geologic timescales. Geomorphology 305:163-

674 172. https://doi.org/10.1016/i.geomorph.2017.09.033

675 Field-Dodgson MS. 1987. The effect of salmon redd excavation on stream substrate 676 and benthic community of two salmon spawning streams in Canterbury, New

677 Zealand. Hydrobiologia 154: 3-11

678 Flecker AS, Taylor BW. 2004. Tropical fishes as biological bulldozers: density effects 679 on resource heterogeneity and species diversity. Ecology 85: 2267-2278.

680 https://doi.org/10.1890/03-0194

681 Flecker AS. 1996. Ecosystem engineering by a dominant detritivore in a diverse 682 tropical stream. Ecology 77: 1845-1854. https://doi.org/10.2307/2265788

683 Flecker AS. 1997. Habitat modification by tropical fishes: environmental 684 heterogeneity and the variability of interaction strength, Journal of the North 685 American Benthological Society 16: 286-295. https://doi.org/10.2307/1468258

686 Fortino K. 2006. Effect of season on the impact of ecosystem engineers in the New 687 River, NC, Hydrobiologia 559: 463-466, https://doi.org/10.1007/s10750-005-5325-5

688 Gido KB, Matthews WJ. 2001. Ecosystem effects of water column minnows in 689 experimental streams. Oecologia 126: 247-253.

690 https://doi.org/10.1007/s004420000505

691 Giriat D, Gorczyca E, Sobucki M. 2016. Beaver ponds' impact on fluvial processes 692 (Beskid Niski Mts., SE Poland). Science of the Total Environment 544: 339-353. 693 https://doi.org/10.1016/j.scitotenv.2015.11.103

694 Gottesfeld AS, Hassan MA, Tunnicliffe JF, Poirier AW. 2004. Sediment dispersion in 695 salmon spawning streams: The influence of floods and salmon redd construction. 696 Journal of the American Water Resources Association 40: 1071-1086.

697 https://doi.org/10.1111/j.1752-1688.2004.tb01068.x

698 Gottesfeld AS, Hassan MA, Tunnicliffe JF. 2008. Salmon bioturbation and stream 699 process. American Fisheries Society Symposium 65: 175 - 193

700 Gurnell, A.M., 1998. The hydrogeomorphological effects of beaver dam-building 701 activity. Progress in Physical Geography 22: 167-189.

702 https://doi.org/10.1177/030913339802200202

703 Hall K, Lamont N. 2003. Zoogeomorphology in the Alpine: some observations on 704 abiotic-biotic interactions. Geomorphology 55: 219-234.

705 https://doi.org/10.1016/S0169-555X(03)00141-7

706 Harvey G, Henshaw A, Moorhouse TP, Clifford NJ, Holah H, Grey J, Macdonald D. 707 2014. Invasive crayfish as drivers of fine sediment dynamics in rivers: field and 
708

709

710

711

712

713

714

715

716

717

718

719

720

721

722

723

724

725

726

727

728

729

730

731

732

733

734

735

736

737

738

739

740

741

742

743

744

laboratory evidence. Earth Surface Processes and Landforms 39: 259-271. https://doi.org/10.1002/esp.3486

Harvey G, Moorhouse TP, Clifford NJ, Henshaw A, Johnson MF, MacDonald DW, Reid I, Rice SP. 2011. Evaluating the role of invasive aquatic species as drivers of fine sediment-related river management problems: the case of the signal crayfish (Pacifastacus leniusculus). Progress in Physical Geography 35: 517-533. https://doi.org/10.1177/0309133311409092

Hassan MA, Gottesfeld AS, Montgomery DR, Tunnicliffe JF, Clarke GKC, Wynn G, Jones-Cox H, Poirier R, Maclsaac E, Herunter H and Macdonald SJ. 2008. Salmondriven bedload transport and bed morphology in mountain streams. Geophysical Research Letters 35: L04405. https://doi.org/10.1029/2007GL032997

Hassan MW, Tonina D, Buxton TH. 2015. Does small-bodied salmon spawning activity enhance streambed mobility? Water Resources Research 51: 7467-7484. https://doi.org/10.1002/2015WR017079

Holtmeier F-K. 2015. Animals' Influence on the Landscape and Ecological Importance: Natives, Newcomers, Homecomers. Springer, London. https://doi.org/10.1007/978-94-017-9294-3

Janssen J. 1976. Feeding modes and prey size selection in the alewife (Alosa pseudoharengus). Journal of the Fisheries Research Board of Canada 33: 19721975. https://doi.org/10.1139/f76-251

Janssen J. 1978. Feeding-behavior repertoire of the alewife, Alosa pseudoharengus, and the ciscoes Coregonus hoyi and C. artedii. Journal of the Fisheries Research Board of Canada 35: 249-253. https://doi.org/10.1139/f78-040

Johnson MF, Reid I, Rice SP, Wood J. 2009. Stabilisation of fine gravels by netspinning caddisfly larvae. Earth Surface Processes and Landforms 34: 413-423. https://doi.org/10.1002/esp.1750

Johnson MF, Rice SP, Reid I. 2011. Increase in coarse sediment transport associated with disturbance of gravel river beds by signal crayfish (Pacifastacus leniusculus). Earth Surfaces Processes and landforms 36: 1680-1692. https://doi.org/10.1002/esp.2192

Jones CG, Lawton JH, Shachak M. 1994. Organisms as ecosystem engineers. Oikos 69 373-386. https://doi.org/10.2307/3545850

Jones CG. 2012. Ecosystem engineers and geomorphological signatures in landscapes. Geomorphology 157-158: 75-87.

https://doi.org/10.1016/i.geomorph.2011.04.039

Jouquet P, Henry-des-Tureaux T. Mathieu J., Thu TD, Duc TT, and Orange D. 2010. Utilization of near infrared reflectance spectroscopy (NIRS), to quantify the impact of 
earthworms on soil and carbon erosion in steep slope ecosystem: A study case in Northern Vietnam. Catena 81: 113-116. https://doi.org/10.1016/i.catena.2010.01.010

747 Kirchner JW, Dietrich WE, Iseya F, Ikeda H. 1990. The variability of critical shear 748 stress, friction angle, and grain protrusion in water - worked sediments.

749 Sedimentology 37: 647-672. https://doi.org/10.1111/j.1365-3091.1990.tb00627.x

750 Komar PD, Li Z. 1986. Pivoting analyses of the selective entrainment of sediments 751 by shape and size with application to gravel threshold. Sedimentology 33: 425-436.

752 https://doi.org/10.1111/j.1365-3091.1986.tb00546.x

753 Kondolf GM, Sale MJ and Wolman MG. 1993. Modification of fluvial gravel size by

754 spawning salmonids. Water Resources Research 20: 2265 - 2274.

755 https://doi.org/10.1029/93WR00401

756 Lachner EA. 1952. Studies of the biology of the cyprinid fishes of the chub genus

757 nocomis of northeastern United States. American Midland Naturalist 48: 433-466

758 Larsen A, Alvarez N, Sperisen C, Lane SN. 2017. Biotic drivers of river and 759 floodplain geomorphology - New molecular methods for assessing present-day and 760 past biota. Earth Surface Processes and Landforms 43: 333-338.

761 https://doi.org/10.1002/esp.4238

762 Maitland PS. 2004. Keys to the freshwater fish of Britain and Ireland, with notes on 763 their distribution and ecology. Freshwater Biological Association Scientific

764 Publication 62. Freshwater Biological Association, Ambleside UK.

765

766

767

768

769

770

771

772

773

774

775

776

777

778

779

Margenau TL, Gilbert SJ, Hatzenbeler GR. 2003. Angler catch and harvest of northern pike in northern Wisconsin lakes. N. Am. J. Fish. Manage. 23, 307-312. https://doi.org/10.1577/1548-8675(2003)023<0307:ACAHON>2.0.CO;2

Meysman FJR, Middleburg JJ, Heip CHR. 2006. Bioturbation: a fresh look at Darwin's last idea. Trends in Ecology and Evolution 21: 688-695.

https://doi.org/10.1016/j.tree.2006.08.002

Montgomery DR, Buffington JM, Peterson NP, Schuett-Hames D, Quinn TP. 1996. Stream-bed scour, egg burial depths, and the influence of salmonid spawning on bed surface mobility and embryo survival. Canadian Journal of Aquatics and Fisheries Science 53: 1061 - 1070. https://doi.org/10.1139/f96-028

Moore JW. 2006. Animal ecosystem engineers in streams. Bioscience 56: 237-246. https://doi.org/10.1641/0006-3568(2006)056[0237:AEEIS]2.0.CO;2

Naiman, RJ, Elliott, SR, Hellfield, JM, O'Keefe, TC. 2000. Biophysical interactions and the structure and dynamics of riverine ecosystems: the importance of biotic feedbacks. Hydrobiologia 410: 79-86. 
780 National Research Council. 2009. Landscapes on the edge: new horizons for

781 research on Earth's surface. National Academies Press, Washington, D.C., USA.

782 Orlandini S, Moretti G, Albertson JD. 2015. Evidence of an emerging levee failure 783 mechanism causing disastrous floods in Italy. Water Resources Research 51, 7995784 8011. https://doi.org/10.1002/2015WR017426.

785 Peoples BK, Floyd SP, Frimpong EA. 2016. Nesting microhabitat comparison of 786 Central stoneroller and Bluehead chub: potential inference for host-switching by nest 787 associates. Journal of Freshwater Ecology, 31: 251-259,

788 https://doi.org/10.1080/02705060.2015.1091390

789 Pflieger WL. 1966. Reproduction of the smallmouth bass (Micropterus dolomieui) in 790 a small Ozark stream. The American Midland Naturalist 76: 410-418

791 Phillips JD. 2009. Biological energy in landscape evolution. American Journal of 792 Science 309: 271-289. https://doi.org/10.2475/04.2009.01.

793 Pitcher TJ, Parrish JK. 1993. Functions of shoaling behaviour in teleosts. In

794 Behaviour of teleost fishes, Pitcher TJ (ed), Chapman and Hall, 2-6 Boundary Row, 795 London, UK.

796 Pledger, A.G. (2015), Foraging fish as zoogeomorphic agents: their effects on the 797 structure and composition of gravel-bed river sediments with implications for bed 798 material transport, Unpublished PhD thesis, Loughborough University.

799 https://dspace.lboro.ac.uk/dspace-jspui/handle/2134/16680

800 Pledger AG, Rice SP, Millet J. 2014. Reduced bed material stability and increased 801 bedload transport caused by foraging fish: a flume study with juvenile Barbel (Barbus 802 barbus). Earth Surface Processes and Landforms 39: 1500-1513, 803 https://doi.org/10.1002/esp.3592

804 Pledger AG, Rice SP, Millet J. 2016. Bed disturbance via foraging fish increases 805 bedload transport during subsequent high flows and is controlled by fish size and 806 species. Geomorphology 253: 83-93.

807 https://doi.org/10.1016/.geomorph.2015.09.021

808 Pledger AG, Rice SP, Millet J. 2017. Foraging fish as zoogeomorphic agents: an 809 assessment of fish impacts at patch, barform, and reach scales. Journal of 810 Geophysical Research: Earth Surface 122: 2105-2123.

811 https://doi.org/10.1002/2017JF004362

812 Polvi LE, Wohl E. 2012. The beaver meadow complex revisited - the role of beavers 813 in post-glacial floodplain development. Earth Surface Processes and Landforms 36:

814 332-346. https://doi.org/10.1002/esp.2261

815 Power ME. 1990. Resource enhancement by indirect effects of grazers: armored 816 catfish, algae and sediment. Ecology 71: 897-904. https://doi.org/10.2307/1937361 
817 Pringle CM, Hamazaki T. 1998. The role of omnivory in a neotropical stream:

818 separating diurnal and nocturnal effects. Ecology 79: 269-280,

819 https://doi.org/10.1890/0012-9658(1998)079[0269:TROOIA]2.0.CO;2

820 Rice SP, Johnson MF, Reid I. 2012. Animals and the Geomorphology of Gravel-bed

821 Rivers in Church M, Biron P and Roy AG (Eds), Gravel-bed rivers: processes, tools,

822 environments, 225-241. John Wiley and Sons, Chichester.

823 Rice SP, Johnson MF, Mathers K, Reeds J, Extence C. 2016. The importance of 824 biotic entrainment for base flow fluvial sediment transport. Journal of Geophysical 825 Research: Earth Surface 121: 890-906. https://doi.org/10.1002/2015JF003726

826 Rushbrook BJ, Barber I. 2008. A comparison of nest building by three-spined 827 sticklebacks Gasterosteus aculeatus from still and flowing waters. Journal of Fish 828 Biology 73: 746-752. https://doi.org/10.1111/j.1095-8649.2008.01970.x

829 Sabaj MH, Maurakis EG, Woolcott WS. 2000. Spawning behaviors in the bluehead 830 chub, Nocomis leptocephalus, river chub, Nocomis micropogon and central 831 stoneroller, Campostoma anomalum. American Midland Naturalist 144:187-201.

832 Shirakawa H, Yanai S, Goto A. 2013. Lamprey larvae as ecosystem engineers: 833 physical and geochemical impact on the streambed by their burrowing behaviour. 834 Hydrobiologia 701: 313-322.

835 Sibbing FA. 1991. Food capture and oral processing. In: Winfield, IJ \& Nelson, JS 836 (Eds), Cyprinid Fishes Systematics, biology and exploitation. Chapman and Hall, 837 Bury St. Edmunds, pp 377-412.

838 Statzner B, Arens BF, Champagne J-Y, Morel R. Herouin E. 1999. Silk producing 839 stream insects and gravel erosion: significant biological effects on critical shear 840 stress. Water Resources Research 35: 3495-3506.

841 https://doi.org/10.1029/1999WR900196

842 Statzner B, Fièvet E, Champagne J-Y, Morel R, Herouin, E. 2000. Crayfish as 843 geomorphic agents and ecosystem engineers: biological behavior affects sand and 844 gravel erosion in experimental streams. Limnology and Oceanography 45: 10308451040.

846 Statzner B, Sagnes P, Champagne J-Y, Viboud S. 2003. Contribution of benthic fish 847 on the patch dynamics of gravel and sand transport in streams. Water Resources 848 Research 39: 1-17.

849 Statzner B. 2012. Geomorphological implications of engineering bed sediments by 850 lotic animals. Geomorphology 157: 49-65.

851 https://doi.org/10.1016/j.geomorph.2011.03.022 
852 Statzner B, Sagnes P. 2008. Crayfish and fish as bioturbators of streambed

853 sediments: assessing joint effects of species with different mechanistic abilities.

854 Geomorphology 3: 267-287. https://doi.org/10.1016/j.geomorph.2007.02.019

855 Steiger J. Corenblit D. 2012. The emergence of an 'evolutionary geomorphology'?

856 Central European Journal of Geoscience 4: 376-382. https://doi.org/10.2478/s13533-

$857 \quad \underline{011-0075-6}$

858 Stoner, A.W., 2004. Effects of environmental variables of fish feeding ecology:

859 implications for the performance of baited fishing gear and stock assessment. J. Fish

860 Biol. 65, 1445-1471. https://doi.org/10.1111/j.0022-1112.2004.00593.x

861 Thorpe JH. 1988. Patches and the responses of lake benthos to sunfish nest-

862 building. Oecologia 76:168-174. https://doi.org/10.1007/BF00379949

863 Viles HA. 1988. Introduction. In Viles, HA (ed.) Biogeomorphology. Blackwell, New

864 York.

865 Wheaton JM, Gibbins C, Wainright J, Larsen L, McElroy B. 2011. Preface: Multiscale 866 Feedbacks in Ecogeomorphology. Geomorphology 126: 265-268.

867 https://doi.org/10.1016/.geomorph.2011.01.002

868 Wiberg PL, Smith JD.1987. Calculations of the critical shear stress for motion of 869 uniform and heterogeneous sediments. Water Resources Research 23: 1471-1480.

870 https://doi.org/10.1029/WR023i008p01471

871 Winemiller KO, Taylor DH. 1982. Smallmouth bass nesting behaviour and nest site

872 selection in a small Ohio stream. Ohio Journal of Science 82: 266-273.

873 Wright JP, Jones CG. 2006. The concept of organisms as ecosystem engineers ten

874 years on: progress, limitations, and challenges. Bioscience 56: $203-209$.

875 https://doi.org/10.1641/0006-3568(2006)056[0203:TCOOAE]2.0.CO;2

876 
877 Table 1. Fish species recorded in the River Trent catchment and their respective 878 behaviour, weight and benthic impact scores. See methods for details of how the 879 scores were assigned. Feeding Behaviour score (FBS): piscivorous and parasitic $=$ 880 0; opportunistic $=1$; obligate benthic $=2$. Mass score, $\mathrm{MS}: 0-15 \mathrm{~g}=0 ; 16-99 \mathrm{~g}=$ $8811 ; 100-499 \mathrm{~g}=2 ; 500-1499 \mathrm{~g}=3$ and; $1500-4000 \mathrm{~g}=4$.

882

\begin{tabular}{|c|c|c|c|c|}
\hline Latin name & Common name & $\begin{array}{c}\text { Feeding } \\
\text { Behaviour } \\
\text { score } \\
\text { (FBS) }\end{array}$ & $\begin{array}{l}\text { Mass } \\
\text { score } \\
\text { (MS) }\end{array}$ & FBS*MS \\
\hline Salmo salar & Atlantic salmon & 0 & 4 & 0 \\
\hline Lampetra planeri & Brook lamprey & 1 & 0 & 0 \\
\hline Phoxinus phoxinus & Minnow & 1 & 0 & 0 \\
\hline Pungitius pungitius & Nine-spined stickleback & 1 & 0 & 0 \\
\hline Perca fluviatilis & Perch & 0 & 2 & 0 \\
\hline Esox lucius & Pike & 0 & 4 & 0 \\
\hline Lampetra fluviatilis & River lamprey & 0 & 1 & 0 \\
\hline Petromyzon marinus & Sea lamprey & 0 & 2 & 0 \\
\hline Cobitis taenia & Spined loach & 2 & 0 & 0 \\
\hline Barbatula barbatula & Stone loach & 2 & 0 & 0 \\
\hline Gasterosteus aculeatus & Three-spined stickleback & 1 & 0 & 0 \\
\hline Alburnus alburnus & Bleak & 1 & 1 & 1 \\
\hline Salmo trutta & Brown / Sea trout & 1 & 2 & 2 \\
\hline Cottus gobio & Bullhead & 2 & 1 & 2 \\
\hline Leuciscus leuciscus & Dace & 1 & 2 & 2 \\
\hline Carassius auratus & Goldfish & 1 & 2 & 2 \\
\hline Thymallus thymallus & Grayling & 1 & 2 & 2 \\
\hline Gobio gobio & Gudgeon & 2 & 1 & 2 \\
\hline Oncorhynchus mykiss & Rainbow trout & 1 & 2 & 2 \\
\hline Rutilus rutilus & Roach & 1 & 2 & 2 \\
\hline Scardinius erythrophthalmus & Rudd & 1 & 2 & 2 \\
\hline Gymnocephalus cernuus & Ruffe & 2 & 1 & 2 \\
\hline Leuciscus cephalus & Chub & 1 & 3 & 3 \\
\hline Anguilla anguilla & European eel & 1 & 3 & 3 \\
\hline Platichthys flesus & European flounder & 2 & 2 & 4 \\
\hline Blicca bjoerkna & Silver bream & 2 & 2 & 4 \\
\hline Tinca tinca & Tench & 2 & 2 & 4 \\
\hline Barbus barbus & Barbel & 2 & 3 & 6 \\
\hline Abramis brama & Common bream & 2 & 3 & 6 \\
\hline Cyprinus carpio & Common carp & 2 & 4 & 8 \\
\hline
\end{tabular}

883 
885 Table 2. Abundance and extent of 19 fish species scoring FBS $\times$ MS $>0$. Fish were 886 sampled at 176 sites.

887

\begin{tabular}{|c|c|c|c|c|c|}
\hline & FBS*MS & Abundance & $\begin{array}{c}\text { Percent of } \\
\text { scoring } \\
\text { fish }\end{array}$ & $\begin{array}{c}\text { Number of } \\
\text { sites }\end{array}$ & $\begin{array}{c}\text { Percent of } \\
\text { sites }\end{array}$ \\
\hline Bleak & 1 & 26 & 0.085 & 2 & 1.1 \\
\hline Goldfish & 2 & 1 & 0.003 & 1 & 0.6 \\
\hline Rudd & 2 & 5 & 0.016 & 3 & 1.7 \\
\hline Ruffe & 2 & 9 & 0.029 & 3 & 1.7 \\
\hline Rainbow Trout & 2 & 123 & 0.402 & 6 & 3.4 \\
\hline Grayling & 2 & 159 & 0.520 & 23 & 13.1 \\
\hline Dace & 2 & 807 & 2.637 & 52 & 29.5 \\
\hline Gudgeon & 2 & 1181 & 3.860 & 62 & 35.2 \\
\hline Roach & 2 & 1976 & 6.458 & 64 & 36.4 \\
\hline Brown/Sea Trout & 2 & 3059 & 9.997 & 91 & 51.7 \\
\hline Bullhead & 2 & 21800 & 71.244 & 147 & 83.5 \\
\hline Eel & 3 & 335 & 1.095 & 26 & 14.8 \\
\hline Chub & 3 & 985 & 3.219 & 66 & 37.5 \\
\hline Flounder & 4 & 3 & 0.010 & 3 & 1.7 \\
\hline Silver Bream & 4 & 11 & 0.036 & 2 & 1.1 \\
\hline Tench & 4 & 14 & 0.046 & 8 & 4.5 \\
\hline Barbel & 6 & 23 & 0.075 & 7 & 4.0 \\
\hline Common Bream & 6 & 80 & 0.261 & 8 & 4.5 \\
\hline Carp & 8 & 2 & 0.007 & 1 & 0.6 \\
\hline Sum & & 30599 & & & \\
\hline
\end{tabular}




\section{List of Figures}

Figure 1. Common cyprinid feeding behaviours and their impacts on riverbed sediment condition. Grey and black arrows indicate typical magnitudes and directions of fish movements and grain displacements, respectively. Flow direction from right to left. (Credit: Matt Johnson).

Figure 2. The prevalence of different foraging behaviours for a) juvenile Barbel during an ex-situ experiment $(n=5)$ (adapted from Pledger et al. (2014)). and b) juvenile Chub during an in-situ experiment in the River Idle $(n=4)$. Values represent means \pm SE.

Figure 3. Examples of linear foraging scars (black dashed line) in the River Idle, Nottinghamshire, UK.

Figure 4. Factors that may affect foraging impacts on coarse bed material sediments and bed material transport. Note the potential feedbacks from bed material transport to local environmental, predator and prey factors that affect foraging (dashed line).

Figure 5 (a) Map of Trent catchment showing principal tributaries and (b) Sampling sites in the entire data set and those retained for analysis based on quality criteria.

Figure 6. Proportion of fish at each sampling location categorised as specialist benthic feeders, opportunistic benthic feeders or piscivorous. Circle size is proportional to log abundance.

Figure 7. Abundance across 176 sites within the Trent catchment and number of sites occupied by 19 fish species that have FBS $x$ MS $>0$. Circle diameter is proportional to FBS x MS such that larger circles indicate a greater likelihood that foraging by an individual will have a geomorphological impact.

Figure 8. Distribution and abundance of bullhead, barbel and bream, some key benthivorous fish, based on sampling at 176 sites across the Trent catchment. Circle size reflects three abundance categories based on natural breaks in the distribution of values.

Figure 9. Benthic Impact Scores for each site across the Trent catchment ( $\Sigma$ BIS site $_{\text {) }}$. 
Figure 10. Cumulative benthic impact score ( $\left.\Sigma \mathrm{B} I \mathrm{~S}_{\text {species}}\right)$ for all sites across the Trent catchment. Circle diameter is proportional to $\Sigma \mathrm{BIS}$ species and indicates the possible cumulative geomorphic impact of foraging by that species, taking into account site-by-site density $\left(\mathrm{m}^{-2}\right)$, feeding behaviour and average adult mass. Numbers beside the species labels are the percentage of the sum score for all species. 
Figure 1 Approach
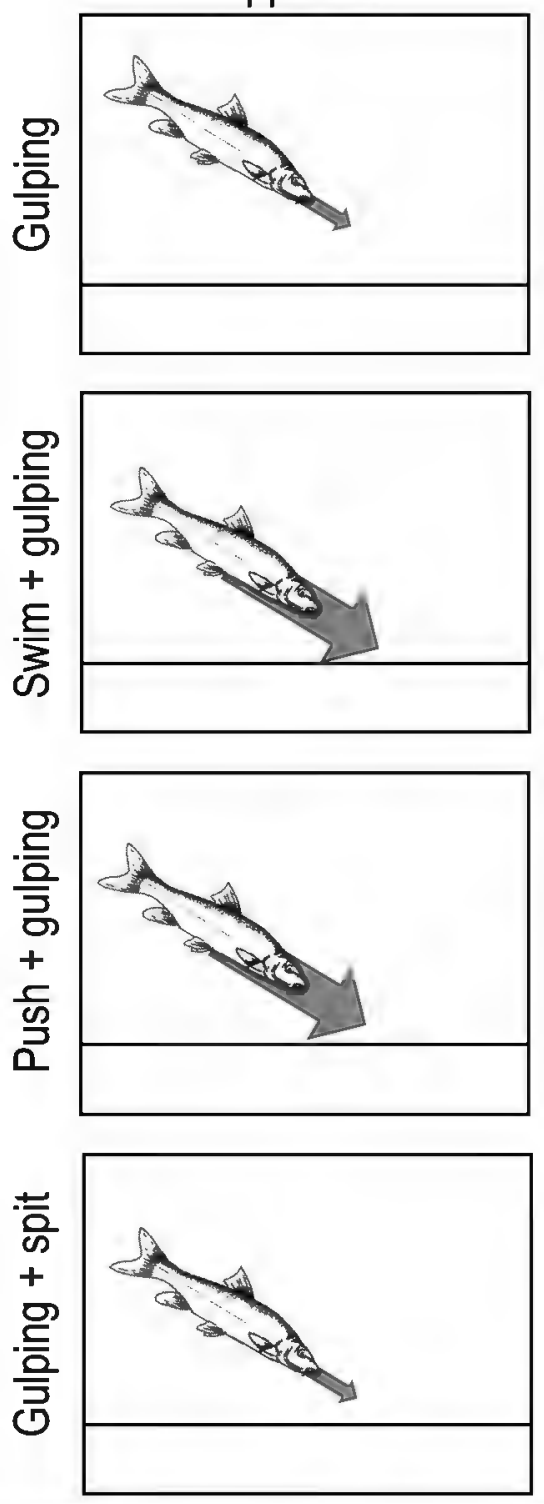

Activity
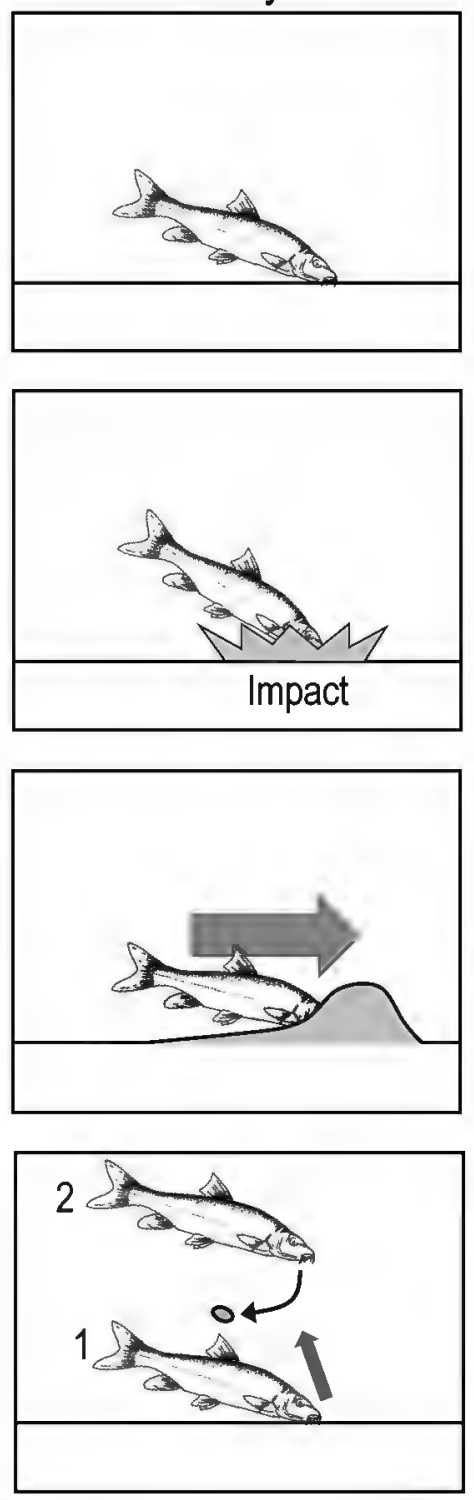

Impact

Grain orientation adjustments
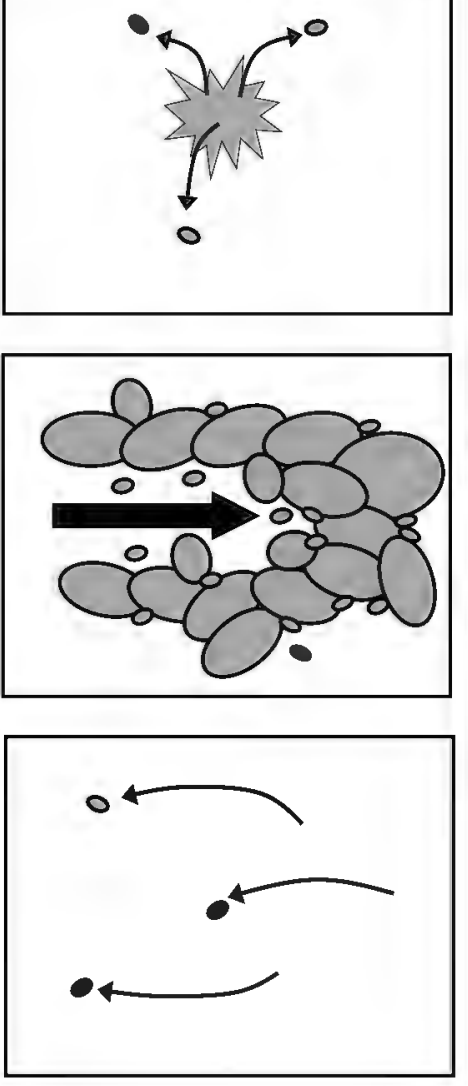

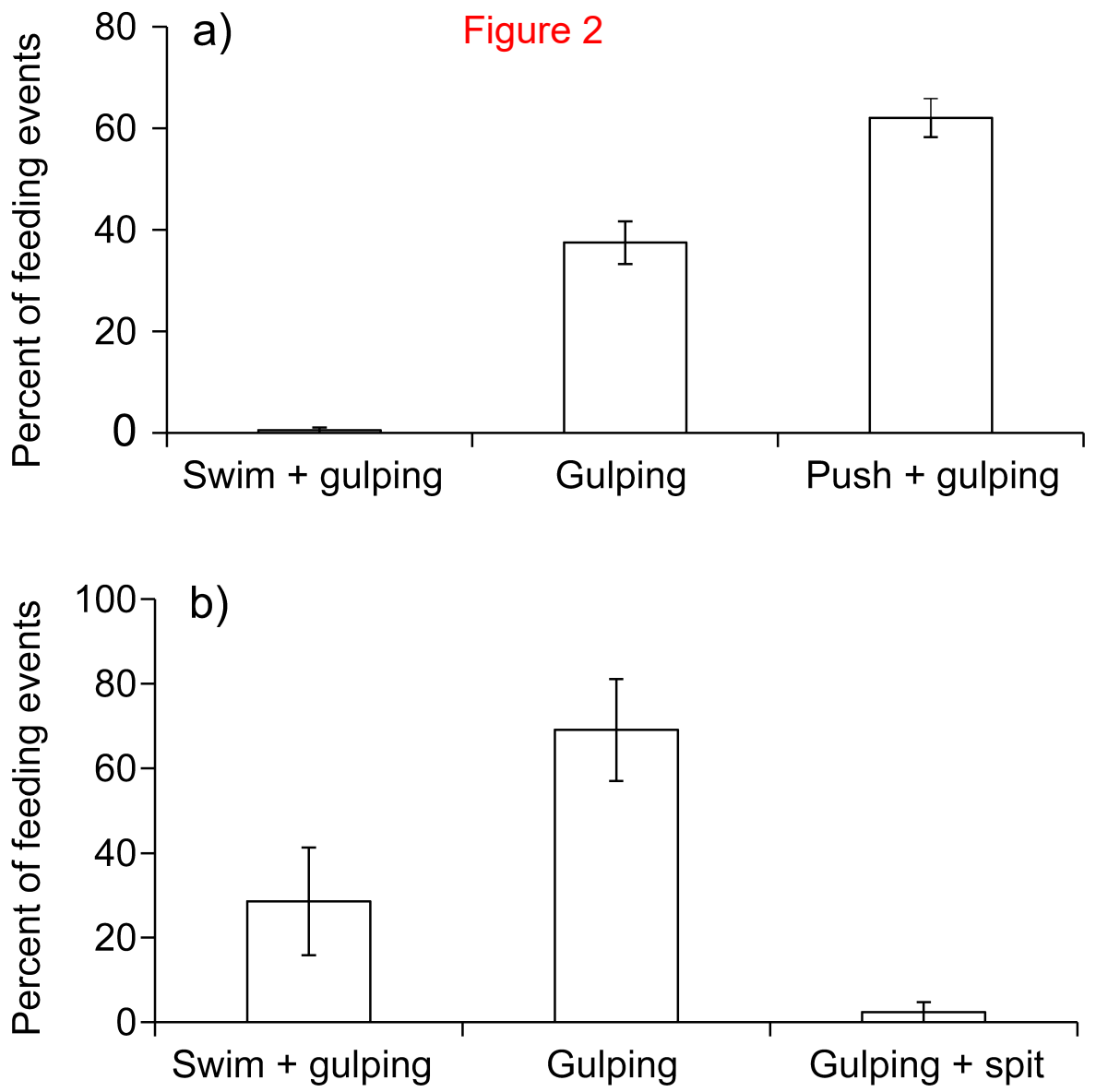


\section{a)}

Figure 3

b)
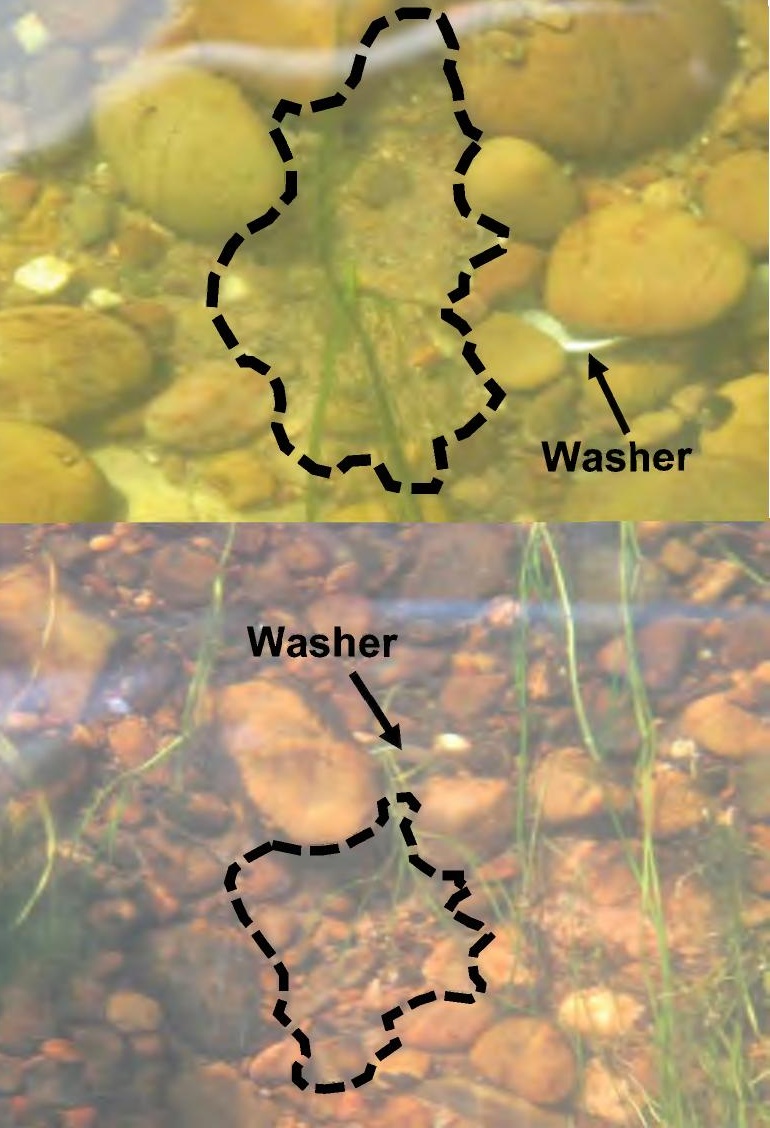

Washer 
Figure 4

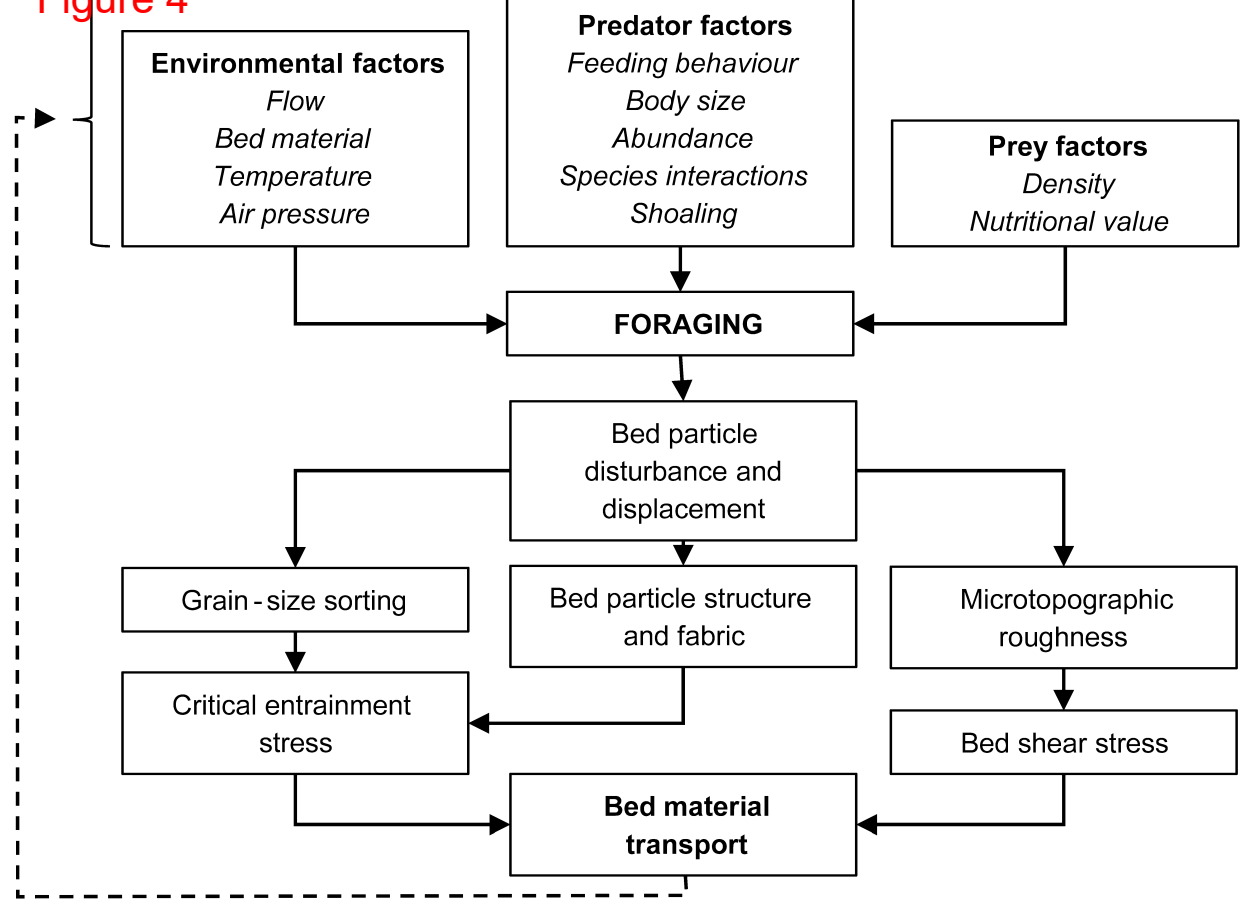




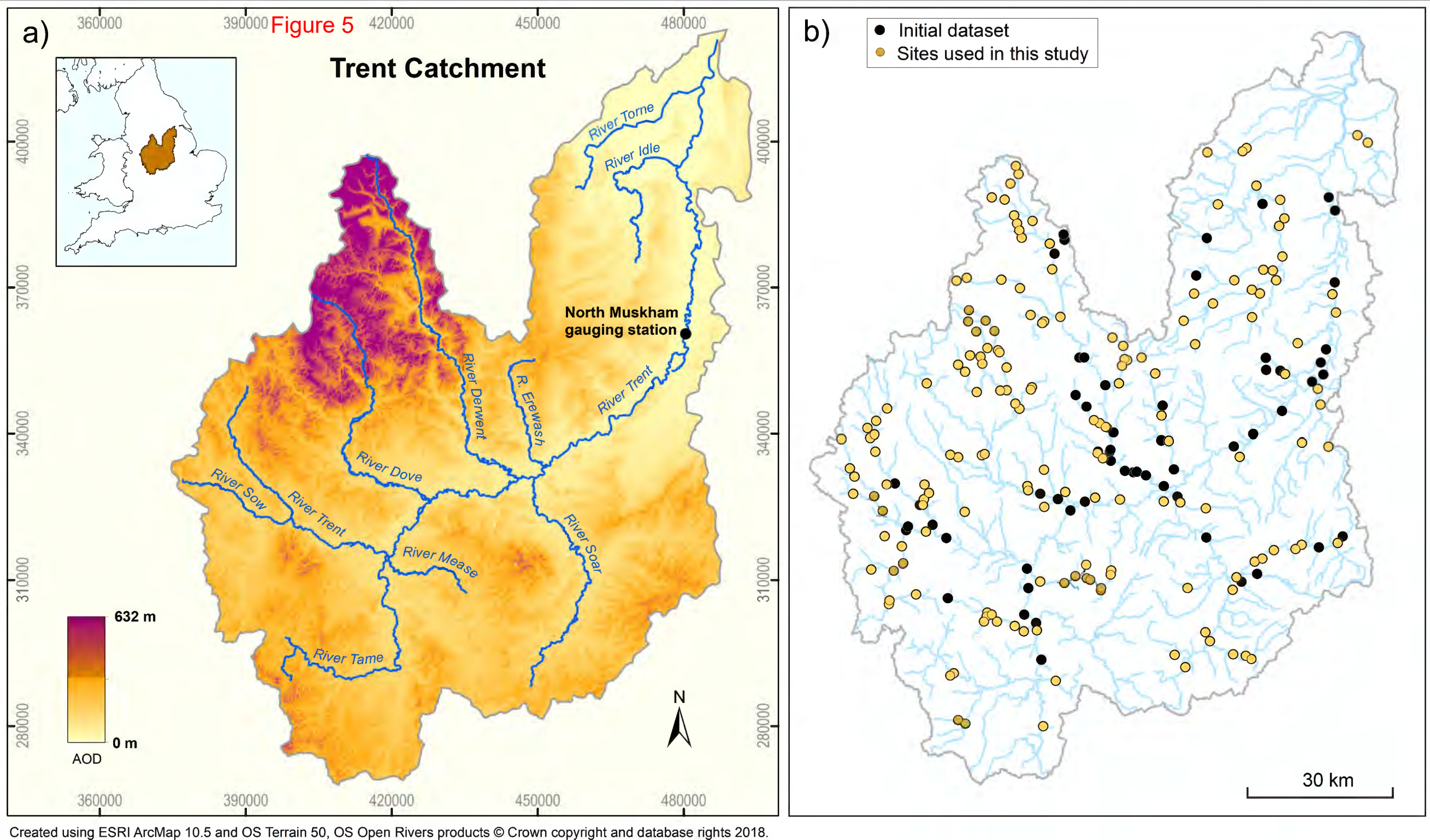

\begin{tabular}{ll}
\hline b) & Initial dataset \\
S Sites used in this study
\end{tabular}

Created using ESRI ArcMap 10.5 and OS Terrain 50, OS Open Rivers products $\odot$ Crown copyright and database rights 2018. Ordnance Survey (Digimap Licence). British National Grid. 


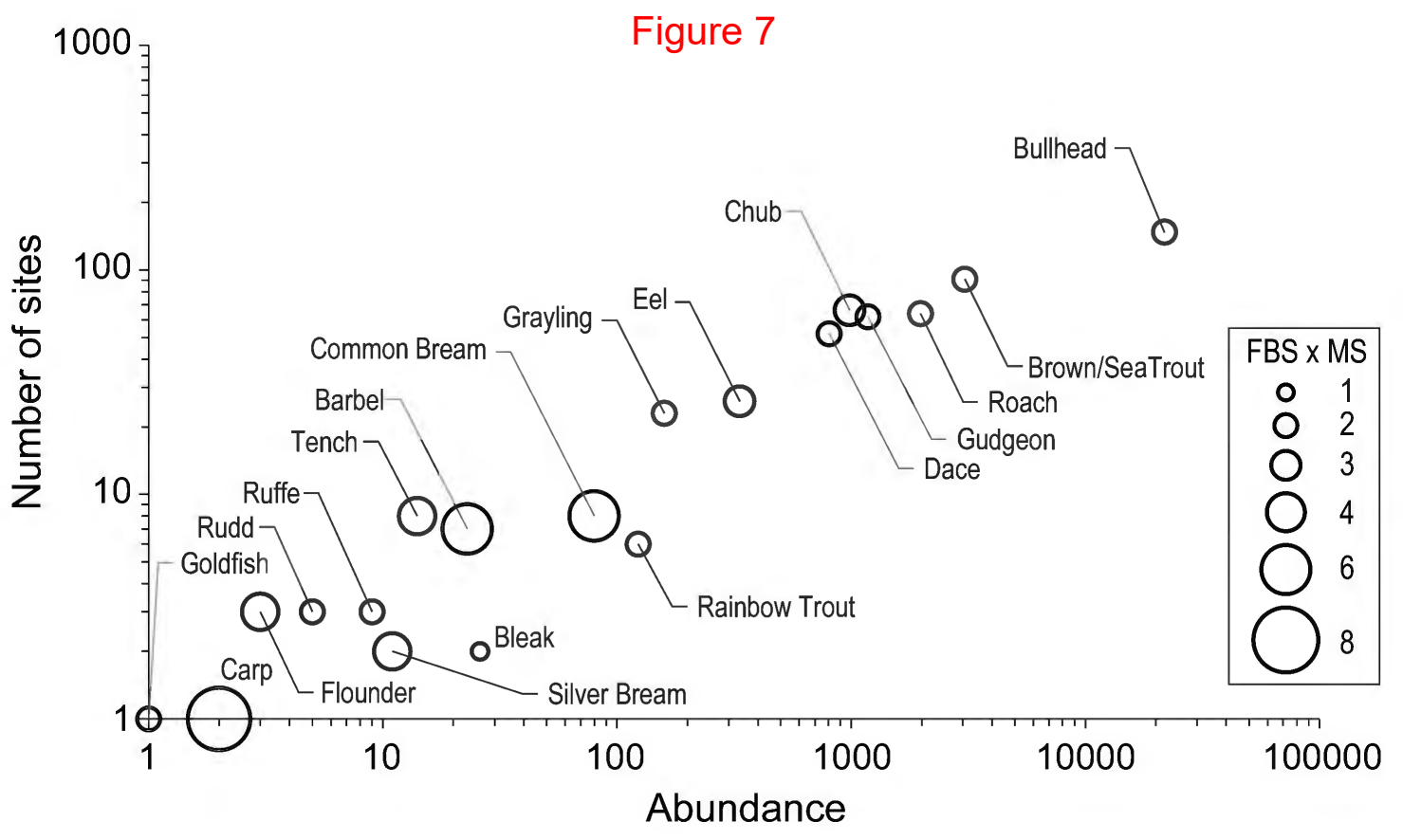


- $1-228$

a) Bullhead

$229-1020$

(1021- 2023

Figure 8

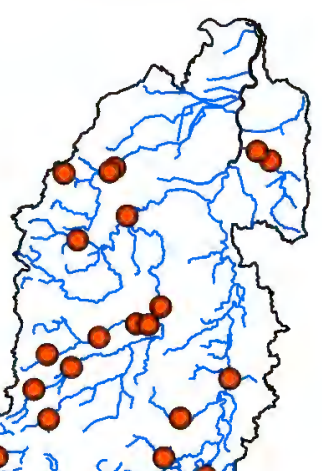

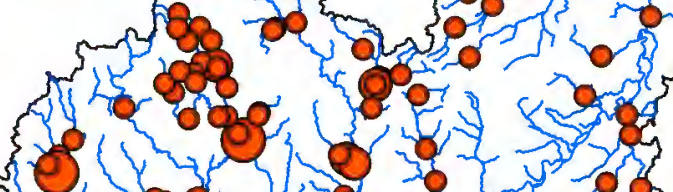

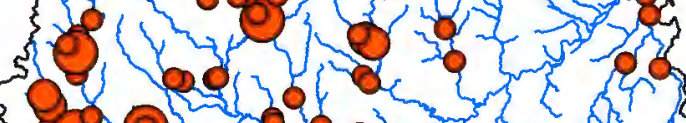

5.4 on 30

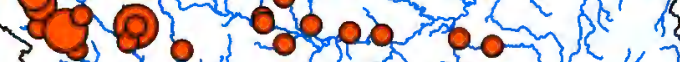

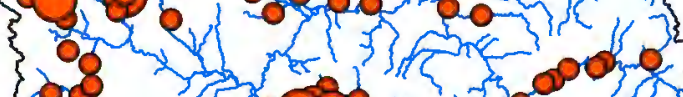

fong

gen na

Ens 4 ,

$\sum_{0}$

$30 \mathrm{~km}$

- $1-3$

b) Barbel \& bream

$9-42$

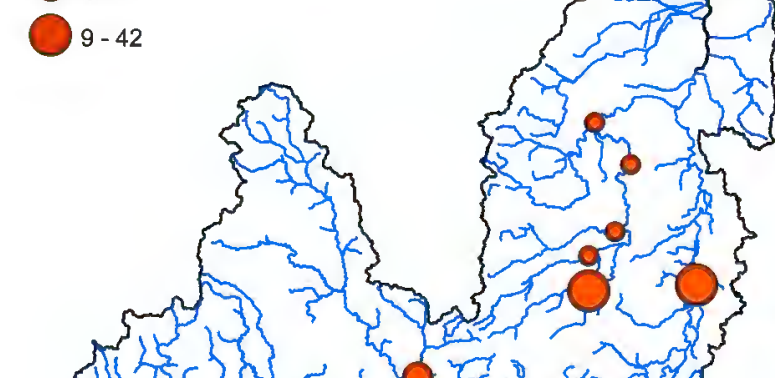

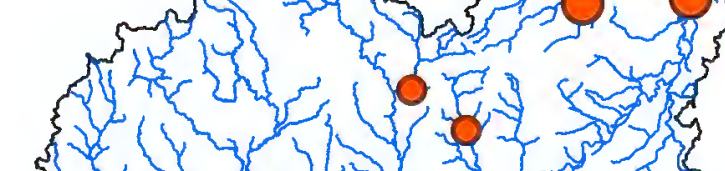

$\xi$

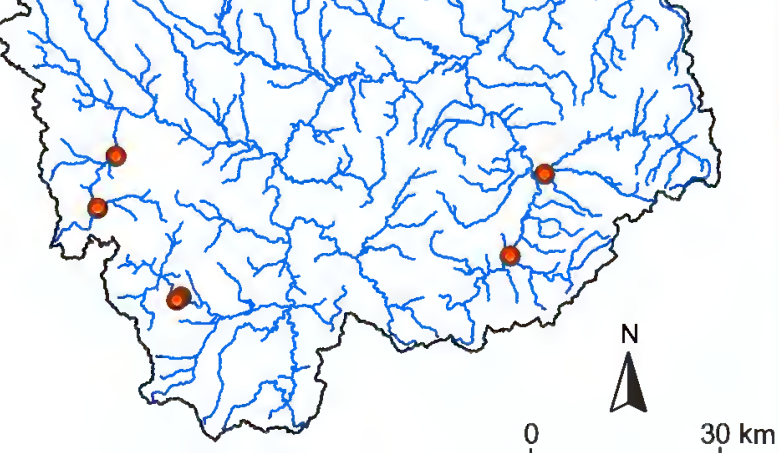


Benthic Impact Score

Figure 9

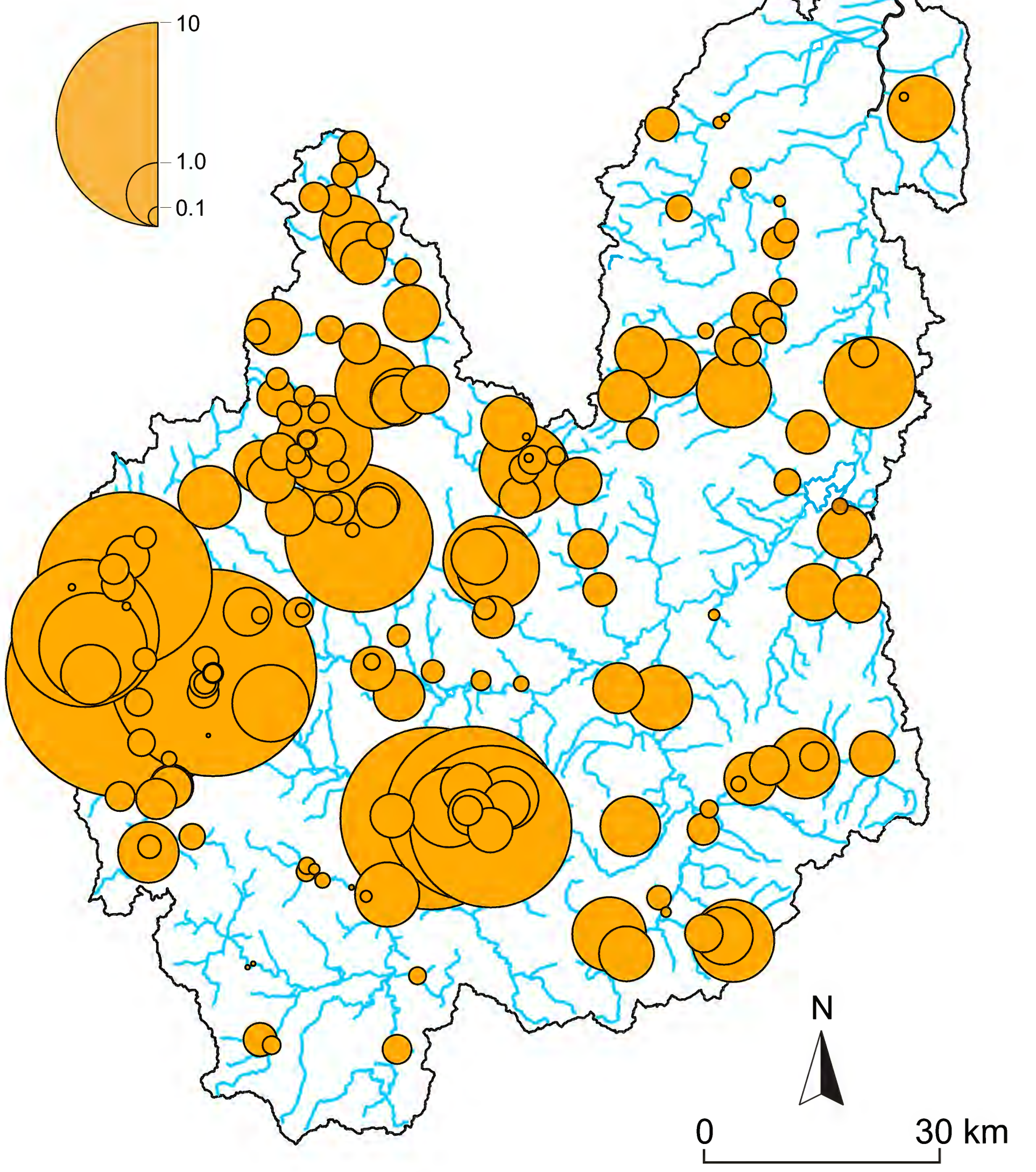




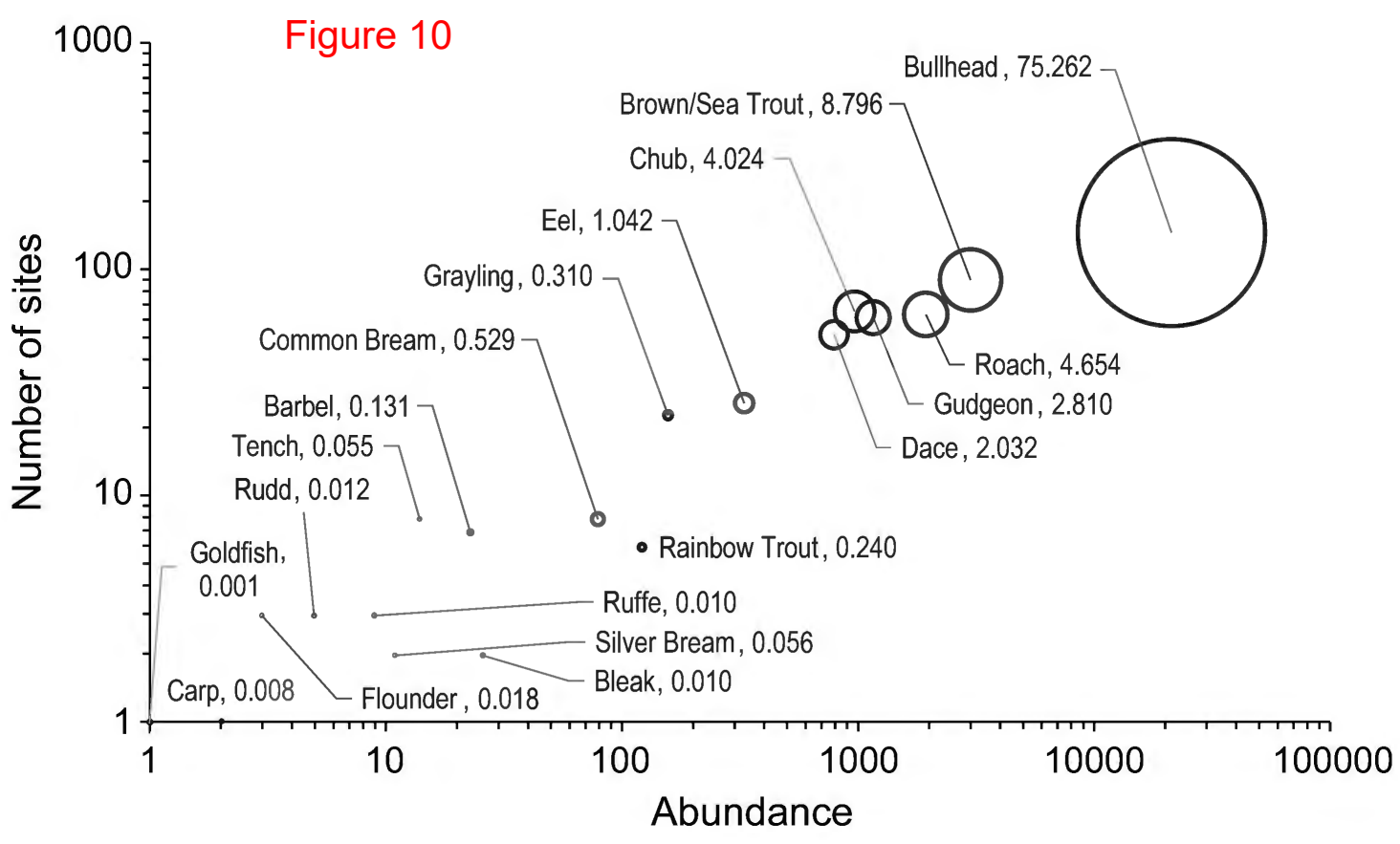

